\title{
DINAMIKA KOMUNITAS FITOPLANKTON DAN KUALITAS PERAIRAN DI LINGKUNGAN PERAIRAN TAMBAK UDANG INTENSIF: SEBUAH ANALISIS KORELASI
}

\section{Phytoplankton Community And Water Quality Dynamics In Aquatic Environmrnt of Intensive Shrimppond: A Corelation Analysis}

\author{
Bambang Widigdo ${ }^{1,2} *$ dan Yusli Wardiatno ${ }^{2}$ \\ 1. Universitas Borneo Tarakan, Jl. Amal Lama No. 1, Tarakan, Kalimantan Utara \\ 2. Departemen Manajemen Sumberdaya Perairan, Fakultas Perikanan dan Ilmu Kelautan, \\ Institut Pertanian Bogor, Kampus Darmaga, Bogor 16680 \\ *Penulis untuk korespondensi: bbg_widigdo@yahoo.id
}

\begin{abstract}
ABSTRAK
Penelitian ini bertujuan mendeskripsikan struktur komunitas fitoplankton di tambak dan perairan sekitarnya dan mengkaji korelasinya dengan kualitas perairan di lingkungan pertambakan udang intensif. Pengambilan sampel air dan fitoplankton dilakukan pada tujuh stasiun di lingkungan dan pada lima tambak. Analisis data yang digunakan adalah indeks similaritas dan analisis komponen utama. Komunitas fitoplankton yang ditemukan terdiri dari 47 genera dari enam kelas yaitu Bacillariophyceae, Dinophyceae, Cyanophyceae, Chlorophyceae, Euglenophyceae, dan Chrysophyceae, dengan dominasi umum Kelas Bacillariophyceae. Sementara pada tambak didominasi oleh Cyanophyceae dan Chlorophyceae. Kelimpahan fitoplankton di tambak cenderung meningkat seiring dengan bertambahnya DOC (Day Of Culture). Kelimpahan fitoplankton menurun pada saluran pembuangan utama (canal main outlet). Penurunan ini diduga akibat adanya percampuran air buangan dengan air laut dan efek sedimentasi di sepanjang saluran tersebut. Indeks similaritas memperlihatkan bahwa air buangan tambak tidak mempengaruhi kelimpahan fitoplankton di lingkungan perairan sekitar area pertambakan dikarenakan konsentrasi limbah yang mencapai lingkungan telah menurun akibat pengenceran pada saluran pembuangan utama. Kelimpahan fitoplankton di lingkungan perairan berkorelasi erat dengan Dissolved Inorganic Nitrogen (DIN), Dissolved Inorganic Phosphate (DIP), dan TSS. Sedangkan di kolam budidaya (tambak), kelimpahan fitoplankton berkorelasi erat dengan DIP, kecerahan, dan salinitas.
\end{abstract}

Kata kunci: fitoplankton, kualitas air, tambak udang, korelasi

\begin{abstract}
The research was amied to reveal phytoplankton community in shrimp ponds and the surrounding waters, and to study the correlation between phytoplankton community and water quality. Water sample and phytoplankton collections were made in seven stations in the surrounding waters and in five shrimp ponds. Similarity index and principal component analyses are used for data analyses. The results showed that 47 genera phytoplankton from six classes (i.e. Bacillariophyceae, Dinophyceae, Cyanophyceae, Chlorophyceae, Euglenophyceae, and Chrysophyceae) were found, and it is dominated by Class Bacillariophyceae in the surrounding waters. While in the shrimp ponds, Cyanophyceae and Chlorophyceae were the two dominants. The abundance of phytoplankton tended to increase with DOC (Day Of Culture). In the shrimp pond area, especially in canal main outlet the abundance decreased due to mixing processes with sea water in the canal. Similarity index
\end{abstract}


indicated that shrimp pond effluent did not affect phytoplankton community of the surrounding waters. In the surrounding waters, phytoplankton abundance was significantly correated with Dissolved Inorganic Nitrogen (DIN), Dissolved Inorganic Phosphate (DIP), and TSS. While in shrimp ponds, it was significantly correlated with DIP, transparency and salinity.

Keywords: phytoplankton, water quality, shrimp pond, correlation

\section{PENDAHULUAN}

$\mathrm{K}$ egiatan budidaya udang selain memberikan keuntungan ekonomis yang tinggi namun juga berpotensi berdampak negatif bagi lingkungan perairan (Burford et al., 2003). Kegiatan budidaya akan menghasilkan limbah berupa bahan organik dan unsur hara terutama $\mathrm{N}$ yang bersumber dari sisa pakan dan eksresi (Jackson et al., 2003). Pengelolaan air berupa pembuangan sebagian air dari tambak adalah upaya umum dalam pengelolaan untuk memastikan kualitas air yang baik bagi pertumbuhan udang yang dipelihara. Air buangan tambak yang mengandung nutrien dan bahan tersuspensi tinggi ini berpotensi mempengaruhi badan air penerima buangan serta dapat menstimulir ledakan pertumbuhan fitoplankton dan menyebabkan kondisi anoksik (Naylor et al., 1998; Smith et al., 1999). Sekitar $80 \%$ dari nitrogen yang dimasukkan ke tambak sebagai pakan udang tidak membentuk biomassa udang dan akan terbuang (Briggs and Funge, 1994; Jackson et al., 2003). Nitrogen sisa dalam tambak dapat berfungsi sebagai bahan bakar plankton dan produksi mikrobial dalam tambak sehingga mampu menciptakan situasi negatif terhadap kualitas air dan sedimen tambak. Kondisi ini dapat menghasilkan komposisi fitoplankton yang tidak dikehendaki pengelola tambak (Moriarty, 1997; Burford and Glibert, 1999). Dari sisi pemulihan kondisi lingkungan secara alami, diperlukan luasan mangrove antara 2-22 hektar untuk mengasimilasi buangan dari setiap hektar tambak udang (Robertson and Phillips, 1995).

Fenomena umum yang terjadi di Indonesia dan wilayah lain di dunia, buangan tambak yang mengandung $22-57 \%$ dari nitrogen yang dimasukkan ke tambak akan mengalir ke perairan sekitarnya baik itu sungai, estuari atau perairan pantai (PaezOsuna et al., 1997; Funge-Smith and Briggs, 1998; Preston et al., 2000; Jackson et al., 2003). Hal ini akan menimbulkan eutrofikasi di badan penerima buangan (Sansanyuth et al., 1996; Naylor et al., 1998). Terkadang pula air buangan ini dipakai sebagai sumber air masukan bagi tambak lainnya. Mekanisme yang demikian dapat menjadi sumber penyebaran penyakit dari tambak ke tambak (Pruder, 1992).

Penelitian tentang efek buangan tambak terhadap kualitas lingkungan perairan badan air penerima relatif terbatas dan data yang ada kerap bercampur dengan efek kegiatan lain seperti pertanian, pemukiman atau industri lain (Grant et al., 1995; Jones et al., 2001). Penelitian-penelitian dengan parameter fisika-kimia telah mengidentifikasi bahwa gejala buangan tambak (e.g. peningkatan nutrien dan konsentrasi klorofil) hanya dapat terukur pada lokasi yang berdekatan dengan sumber buangan (Hensey, 1991; Samocha and Lawrence, 1997), padahal faktanya pengaruh secara biologi dapat mencapai jarak yang lebih jauh (Jones et al., 2001).

Kualitas air lingkungan perairan terkait dengan pengembangan perikanan budidaya menjadi perhatian dunia saat ini, mengingat timbulnya sejumlah efek negatif yang tercatat pada beberapa lokasi (Landesman, 1994; Lacerda et al., 2006). Hal umum namun penting adalah bahwa kualitas air akan mempengaruhi pertumbuhan optimal udang dan panen di tambak. Secara klasik, kajian tentang kualitas air akan mengkombinasikan parameter fisika-kimia dan indikator biologi (Jones et al., 2001). Fakta memperlihatkan bahwa pada budidaya 
tambak intensif melibatkan penambahan pakan buatan, pupuk, dan bahan kimia lain untuk menstabilkan dasar tambak, sehingga penggunaan parameter fisika-kimia untuk mengkaji secara akurat di dalam tambak dan lingkungan sekitarnya menjadi tidak cukup (Wolanski et al., 2000). Tambahan lagi, adanya kelangkaan informasi dalam penggunaan komunitas plankton sebagai indikator biologi terkait dengan kualitas air dalam sistem akuakultur, terutama di lingkungan perairan laut.

Oleh karena itu, parameter biologi dapat digunakan untuk mengkaji efek buangan tambak sebagai tolok ukur keberhasilan pengelolaan tambak dalam arti yang memiliki efek minimal terhadap lingkungan sekitarnya. Cakupan penelitian ini meliputi bagian perairan sebelum adanya kegiatan tambak, lingkungan di dalam kawasan tambak, dan perairan sekitarnya setelah menerima buangan tambak.
Penelitian ini bertujuan untuk mengetahui struktur komunitas fitoplankton serta kaitannya dengan parameter fisika-kimia di tambak dan lingkungan perairan sekitarnya.

\section{BAHAN DAN METODE \\ Waktu dan lokasi penelitian}

Pengambilan contoh air dan fitoplankton dilaksanakan di kawasan tambak udang intensif PT. Centralpertiwi Bahari (CPB) pada bulan Mei sampai September 2008. Sampel diambil dari lingkungan sekitar kawasan tambak dan dari dalam kolam budidaya (tambak).

Pengambilan sampel di lingkungan dilakukan sebanyak tiga kali, yaitu bulan Juli, Agustus, dan September 2008. Lokasi diamati tujuh titik yang meliputi sungai, muara, dan pintu utama air masuk kawasan, masing-masing titik dapat dilihat pada Tabel 1 dan Gambar 1.

Tabel 1. Lokasi stasiun pengambilan contoh di lingkungan sekitar kawasan dan karakteristik masing-masing stasiun

\begin{tabular}{|c|c|c|c|}
\hline \multirow[b]{2}{*}{ Stasiun } & \multicolumn{2}{|c|}{ Letak Geografis } & \multirow[b]{2}{*}{ Karakteristik } \\
\hline & LS & BT & \\
\hline 1 & $4^{\circ} 38^{\prime} 2,2^{\prime \prime}$ & $105^{\circ} 47^{\prime} 0,6^{\prime \prime}$ & $\begin{array}{l}\text { Badan sungai Way Terusan yang belum terkena } \\
\text { dampak aktivitas kawasan }\end{array}$ \\
\hline 2 & $4^{\circ} 38^{\prime} 54,1^{\prime}$, & $105^{\circ} 53^{\prime} 21,1^{\prime \prime}$ & Air laut yang digunakan untuk budidaya \\
\hline 3 & $4^{\circ} 38^{\prime} 35,7^{\prime}$, & $105^{\circ} 53^{\prime} 40,8^{\prime}$, & Titik pembuangan sisa budidaya (sebelum pompa 71) \\
\hline 4 & $4^{\circ} 38^{\prime} 35,7^{\prime}$ & $105^{\circ} 53^{\prime} 37,8^{\prime}$, & Titik pembuangan sisa budidaya (setelah pompa 71) \\
\hline 5 & $4^{\circ} 40^{\prime} 28,9^{\prime}$, & $105^{\circ} 51^{\prime} 19,1^{\prime \prime}$ & Perairan umum yang menerima buangan budidaya \\
\hline 6 & $4^{\circ} 38^{\prime} 00,7^{\prime}$ & $105^{\circ} 53^{\prime} 22,6^{\prime}$, & Perairan umum yang menerima buangan budidaya \\
\hline 7 & $4^{\circ} 40^{\prime} 41,4^{\prime \prime}$ & $105^{\circ} 51^{\prime} 40,8^{\prime}$, & Muara sungai Way Terusan \\
\hline
\end{tabular}

Sampel di dalam kawasan diambil dari 5 tambak (kolam budidaya) dimulai dari awal budidaya hingga mendekati panen setiap 10 hari. Adapun kelima tambak yang diamati adalah 71.09.21; 71.09.22; 71.09.23; 71.10.22; 71.10.23 dan lokasi kelima tambak tersebut dapat dilihat pada Gambar 2.
Identifikasi sampel plankton dilakukan menggunakan mikroskop, Sedgewick Rafter Counting Cell, dan buku identifikasi plankton dari Yamaji (1996) dan Mizuno (1979). Bahan yang digunakan untuk mengawetkan plankton adalah larutan lugol. 


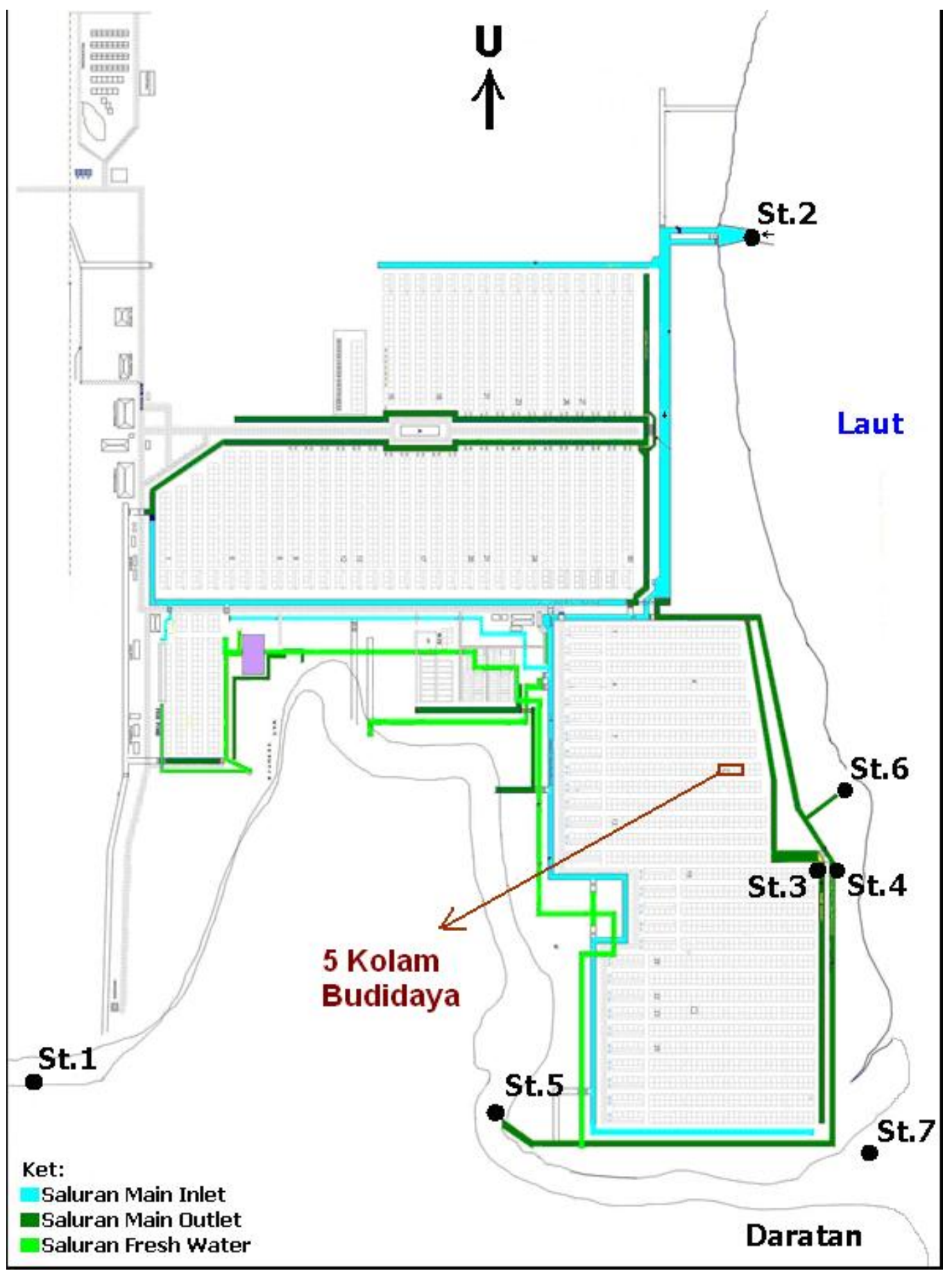

Gambar 1. Lokasi stasiun pengambilan contoh

Pengambilan contoh air dan fitoplankton Fitoplankton

Sampel fitoplankton diambil di kolom air bagian atas (permukaan) menggunakan Simple Sampler lalu disaring menggunakan plankton net dengan mesh size $24 \mu \mathrm{m}$. Volume air yang disaring tergantung dari tingkat kepekatan air yaitu di stasiun 1 sebanyak 100 liter, stasiun 2 dan 7 masingmasing sebanyak 20 liter dan stasiun 3, 4, 5, 
6 masing-masing sebanyak 10 liter. disaring dari kolam budidaya berkisar antara Sementara itu volume sampel air yang 0,6-6 liter (Tabel 2).

Tabel 2. Volume air yang disaring selama pengamatan pada tambak (kolam budidaya).

\begin{tabular}{lcccccccccccc}
\hline DOC & 0 & 10 & 20 & 30 & 40 & 50 & 60 & 70 & 80 & 90 & 100 & 110 \\
\hline $\begin{array}{l}\text { Volume } \\
\text { (liter) }\end{array}$ & 6 & 6 & 6 & 6 & 1,2 & 1,2 & 1,2 & 1,2 & 0,6 & 0,6 & 0,6 & 0,6 \\
\hline
\end{tabular}

Sampel fitoplankton yang tersaring kemudian dimasukkan ke dalam botol sampel berukuran $50 \mathrm{ml}$ dan diawetkan menggunakan 3 - 5 tetes larutan lugol. Selanjutnya dilakukan identifikasi di Laboratorium Integrated Quality Assurance (IQA) PT. Centralpertiwi Bahari. Identifikasi fitoplankton dilakukan dengan metode strip pada Sedgewick Rafter Cell (SRC) di bawah mikroskop dengan perbesaran 100 kali.

Pengukuran parameter fisika-kimia perairan

Parameter yang diukur terdiri dari parameter yang diukur secara in situ dan diukur di laboratorium. Parameter fisikakimia yang diukur disajikan dalam Tabel 3. Parameter yang diukur langsung di lokasi (in situ) adalah suhu, $\mathrm{pH}$, kecerahan, salinitas, dan oksigen terlarut. Contoh air yang tidak dapat dianalisis secara langsung di lapangan diambil menggunakan simple sampler di permukaan. Air yang didapat dimasukkan ke dalam botol sampel plastik berukuran $600 \mathrm{ml}$ dan dianalisis di Laboratorium Integrated Quality Assurance (IQA) PT. Centralpertiwi Bahari.

Tabel 3. Parameter fisika dan kimia yang diukur.

\begin{tabular}{rlll}
\hline No. & Parameter & Unit & Alat \\
\hline A. Fisika & & \\
1 Suhu & ${ }^{\circ} \mathrm{C}$ & DO meter YSI 51 B \\
2 & Kecerahan & $\mathrm{Cm}$ & Secchi disk \\
3 & TSS & $\mathrm{mg} / 1$ & Kertas saring, vacum pump, timbangan analitik \\
4 Salinitas & $\mathrm{psu}$ & Refraktometer \\
\hline B. Kimia & & \\
5 pH & - & $\mathrm{pH}$ meter \\
6 DO & $\mathrm{mg} / 1$ & DO meter YSI 51 B \\
7 & Amonia & $\mathrm{mg} / 1$ & Spektrofotometer \\
8 & Nitrit & $\mathrm{mg} / 1$ & Spektrofotometer \\
9 & Nitrat & $\mathrm{mg} / 1$ & Spektrofotometer \\
10 & Orthofosfat & $\mathrm{mg} / 1$ & Spektrofotometer \\
\hline
\end{tabular}

\section{Analisis data}

Analisis data yang digunakan pada penelitian ini adalah Uji Kruskal-Wallis, Indeks Sumilaritas dan Analisis Komponen Utama. Penghitungan dibantu dengan program komputer yang relevan. Uji Kruskal-Wallis digunakan untuk mengetahui apakah terdapat perbedaan kelimpahan fitoplankton pada umur budidaya (DOC) yang diamati. Indeks Similaritas digunakan untuk melihat indikasi adanya dampak air buangan terhadap lingkungan sekitar tambak berdasarkan pengelompokan stasiun dengan data kelimpahan fitoplankton. Sedangkan Analisis Komponen Utama untuk menentukan korelasi parameter fisika-kimia dengan komunitas fitoplankton. 


\section{HASIL DAN PEMBAHASAN}

\section{Fitoplankton}

Fitoplankton yang ditemukan di seluruh stasiun terdiri dari 47 genera dari enam kelas. Keenam kelas tersebut antara lain Bacillariophyceae (23 genus),
Dinophyceae (8 genus), Cyanophyceae (11 genus), Chlorophyceae (2 genus), Euglenophyceae (1 genus), dan Chrysophyceae (2 genus). Adapun genus yang ditemukan pada masing-masing kelas dapat dilihat pada Tabel 4.

Tabel 4. Genus fitoplankton yang ditemukan selama pengamatan di seluruh stasiun

\begin{tabular}{|c|c|}
\hline Kelas & Genus \\
\hline Bacillariophyceae & $\begin{array}{l}\text { Amphiphora, Asterionella, Bacteriastrum, Biddulphia, } \\
\text { Cerataulina, Chaetoceros, Coscinodiscus, Cyclotella, } \\
\text { Ditylum, Gyrosigma, Melosira, Navicula, Nitzschia, } \\
\text { Pleurosigma, Rhizosolenia, Skeletonema, Stephanodiscus, } \\
\text { Straurastrum, Streptotecha, Thallassionema, Thallassiosira, } \\
\text { Thallassiothrix, Triceratium }\end{array}$ \\
\hline Dinophyceae & $\begin{array}{l}\text { Alexandrium, Ceratium, Dinophysis, Gymnodinium, } \\
\text { Noctiluca, Peridinium, Prorocentrum, Protoperidinium }\end{array}$ \\
\hline Cyanophyceae & $\begin{array}{l}\text { Anabaena, Anabaenopsis, Aphanizomenon, Chroococcus, } \\
\text { Coelosphaerium, Gomphosphaeria, Merismopedia, } \\
\text { Microcystis, Nostoc, Oscillatoria, Spirulina }\end{array}$ \\
\hline Chlorophyceae & Closterium, Oocystis \\
\hline Euglenophyceae & Euglena \\
\hline Chrysophyceae & Cosmocladium, Dictyocha \\
\hline
\end{tabular}

\section{Komposisi fitoplankton}

Komposisi fitoplankton di lingkungan

Komposisi kelas berdasarkan kelimpahan fitoplankton yang ditemukan selama pengamatan didominasi oleh kelas Bacillariophyceae (diatom) pada hampir semua stasiun pengamatan kecuali stasiun 3 dan 4. Hal ini sesuai yang dikemukakan oleh Raymont (1963) dan Arinardi et al. (1994) bahwa kelas fitoplankton yang sering dijumpai di laut dalam jumlah yang besar adalah Kelas Bacillariophyceae. Nontji (2007) juga menyatakan bahwa fitoplankton yang biasa atau umum tertangkap oleh jaring plankton umumnya tergolong dalam tiga kelompok utama yakni diatom, dinoflagellata dan alga biru (blue-green algae). Casé et al. (2008) yang meneliti komposisi fitoplankton di tambak udang di negara Brazil menemukan juga dominasi diatom (Kelas Bacillariophyceae) hampir 70\%. Di perairan Indonesia diatom paling sering ditemukan, baru kemudian dinoflagellata. Alga biru jarang dijumpai, tetapi sekali muncul sering populasinya sangat besar. Namun, faktor yang menjadi penyebabnya tidak disebutkan. Persentase kelas fitoplankton yang ditemukan pada masing-masing stasiun setiap bulan dapat dilihat pada Gambar 4 . 

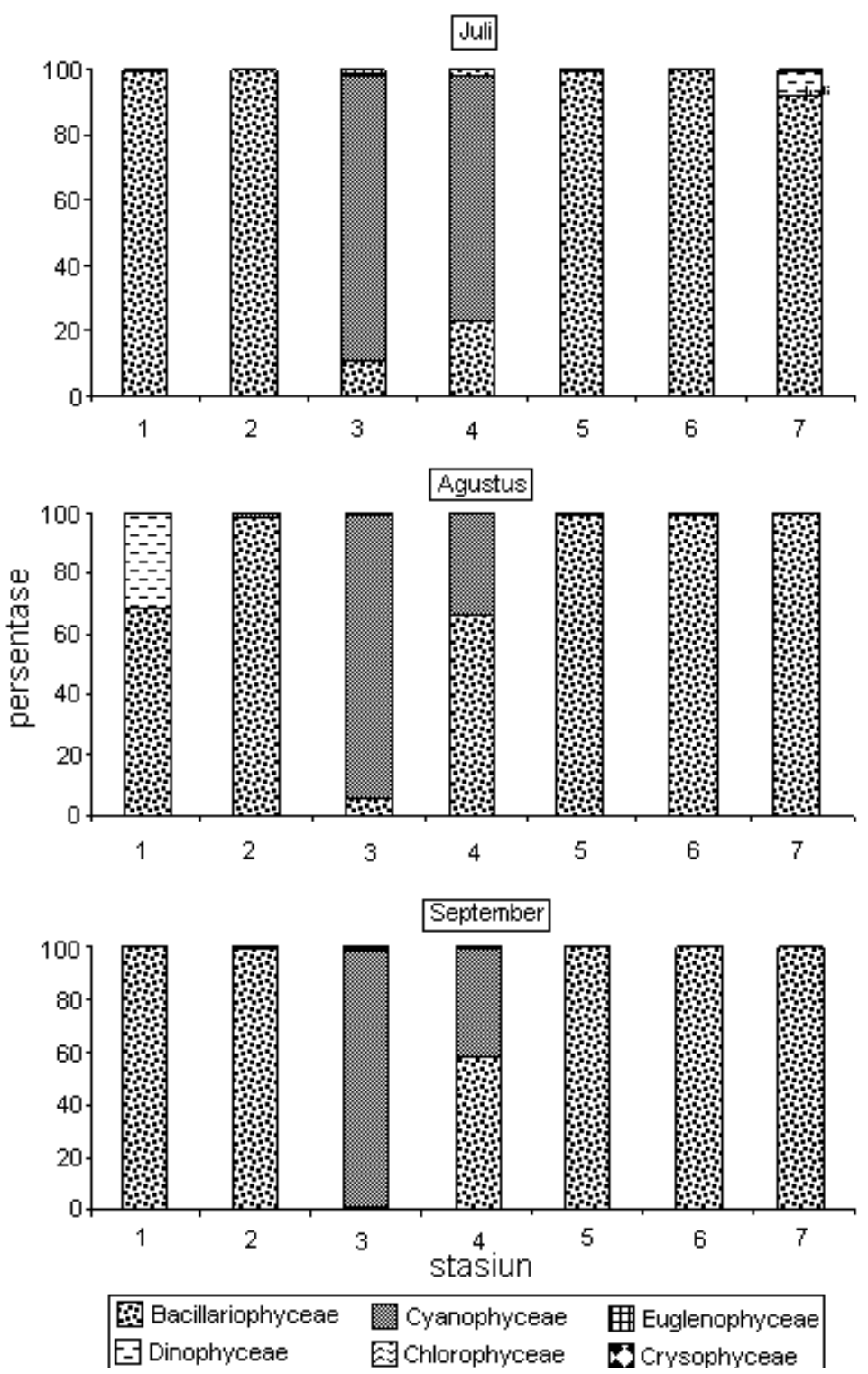

Gambar 4. Komposisi fitoplankton (\%) berdasarkan kelimpahan dari masing-masing kelas pada setiap bulan pengamatan

Stasiun 1, 2, 5, 6, dan 7 didominasi oleh kelas Bacillariophyceae dengan persentase berkisar 68,4 - $100 \%$. Persentase kelas Dinoflagellata berkisar 0 - 30,7 \% dan proporsi kelas-kelas lainnya hanya ditemukan di bawah $10 \%$ dari total jenis fitoplankton yang dicacah. Proporsi kelas Bacillariophyceae pada stasiun 3 dan 4 hanya 1,2 - 66,8 \%, sedangkan proporsi kelas Cyanophyceae lebih besar yaitu 32,5 $97,3 \%$. Persentase kelas-kelas lainnya ditemukan di bawah $10 \%$. Proporsi Cyanophyceae yang tinggi di kedua stasiun ini dapat disebabkan oleh rasio $\mathrm{N}$ : $\mathrm{P}$ yang rendah dimana rasio $\mathrm{N}$ : $\mathrm{P}$ yang terukur hanya sekitar 2 : 1. Baffico and Pedrozo (1996) menyatakan bahwa Cyanophyceae ditemukan lebih dominan pada rasio $\mathrm{N}: \mathrm{P}$ yang rendah yaitu di bawah $10: 1$. Hal ini juga didukung oleh pernyataan Plinski and Jozwiak (1999) bahwa persentase alga hijau biru meningkat pada saat rasio $\mathrm{N}$ : $\mathrm{P}$ adalah 
6,5 : 1. Dalam keadaan seperti ini $\mathrm{N}$ menjadi faktor pembatas di kolom air, sedangkan Cyanophyceae mampu mengikat $\mathrm{N}$ dari udara bebas sehingga Cyanophyceae akan lebih cepat tumbuh dibandingkan kelas-kelas lainnya. Menurut Edhy et al. (2003), beberapa genus dari kelompok Cyanophyceae yang berbentuk benang memiliki sel khusus yang disebut heterocysta yang mampu mengikat nitrogen bebas dari udara (fiksasi nitrogen), sehingga jenis ini dapat bertahan hidup dalam perairan yang memiliki konsentrasi nitrogen yang rendah sementara jenis lain tidak dapat melakukannya. Edhy et al. (2003) selanjutnya menambahkan jenis BGA ada yang mengeluarkan racun penyebab bau lumpur (Geosmin) sehingga udang atau ikan yang dibudidayakan berbau tanah (off flavour).

Penyebab lain tingginya persentase Cyanophyceae di stasiun 3 dan 4 adalah tingginya konsentrasi fosfat di lokasi ini dan hal tersebut pernah dikemukakan oleh Prowse (1962) dan Mackentum (1969) bahwa jenis Cyanophyceae akan mendominasi perairan yang berkadar fosfat lebih dari $0,10 \mathrm{mg} / \mathrm{l}$. Pada kedua lokasi ini kadar rata-rata orthofosfat (DIP) yang didapat dari tiga bulan pengamatan adalah $0,93 \mathrm{mg} / 1$ dan $0,84 \mathrm{mg} / 1$, berbeda dengan stasiun-stasiun lainnya yang tidak melebihi $0,10 \mathrm{mg} / \mathrm{l}$. Rasio N : P dan konsentrasi orthofosfat (DIP) rata-rata dapat dilihat pada Tabel 6.

Tabel 6. Rasio N : P dan konsentrasi orthofosfat (DIP) rata-rata selama pengamatan di lingkungan

\begin{tabular}{|l|c|c|c|c|c|c|c|}
\hline \multirow{2}{*}{ Parameter } & \multicolumn{7}{|c|}{ Stasiun } \\
\cline { 2 - 8 } & 1 & 2 & 3 & 4 & 5 & 6 & 7 \\
\hline $\mathrm{N}: \mathrm{P}$ & 61 & 13 & 2 & 2 & 8 & 12 & 11 \\
\hline $\mathrm{DIP}(\mathrm{mg} / \mathrm{l})$ & 0,01 & 0,07 & 0,93 & 0,84 & 0,06 & 0,05 & 0,04 \\
\hline
\end{tabular}

Rasio $\mathrm{N}$ : $\mathrm{P}$ yang optimal bagi pertumbuhan fitoplankton adalah $16: 1$, rasio ini disebut dengan Redfield Ratio (Sanders, 2004). Rasio N : P di bawah 16 : 1 mengindikasikan $\mathrm{N}$ menjadi faktor pembatas dan di atas $16: 1$ mengindikasikan $\mathrm{P}$ yang menjadi faktor pembatas. Menurut Nontji (1984), rasio N/P di perairan terbuka biasanya hampir konstan yaitu sekitar $15: 1$, tetapi pada perairan di dekat pantai rasionya sangat bervariasi.

Arinardi et al. (1995) menyatakan bahwa genus predominan adalah genus yang memiliki komposisi kelimpahan $\geq 10 \%$ dari total komposisi jenis fitoplankton yang ditemukan pada masing-masing stasiun pengamatan. Genus predominan yang paling sering ditemukan di sekitar area pertambakan ini adalah Skeletonema (dari kelas Bacillariophyceae). Arinardi et al. (1997) menyatakan bahwa jenis fitoplankton
Skeletonema sp. Dapat memanfaatkan kadar zat hara lebih cepat daripada diatom lainnya. Hal tersebut dapat menjadi alasan Skeletonema lebih banyak ditemukan dibandingkan dengan genus lainnya. Genus ini ditemukan di hampir semua stasiun kecuali stasiun 3. Pada stasiun 3 lebih banyak ditemukan fitoplankton dari genus Oscillatoria dan Nostoc dan keduanya termasuk ke dalam Kelas Cyanophyceae. Hal ini dikarenakan rata-rata rasio $\mathrm{N}$ : $\mathrm{P}$ pada stasiun ini hanya $2: 1$ selama tiga bulan pengamatan. Pada stasiun 4 juga tercatat bahwa rasio $\mathrm{N}$ : $\mathrm{P}$ tidak begitu berbeda dengan stasiun 3. Akan tetapi, air pada stasiun ini telah bercampur dengan air laut di sekitar area pertambakan sehingga fitoplanktonnya pun ikut tercampur. Genus predominan yang ditemukan di stasiun 4 adalah Skeletonema dan Oscillatoria. 
Stasiun 1 juga memiliki ciri tersendiri karena fitoplankton di daerah ini lebih didominasi oleh genus Coscinodiscus (dari Kelas Bacillariophyceae). Meskipun demikian Skeletonema masih ditemukan dan tergolong juga ke dalam genus predominan. Pada stasiun 1 ditemukan fitoplankton yang kurang baik pada saat pengamatan bulan Agustus 2008 yaitu Prorocentrum (dari Kelas Dinophyceae). Genus ini tergolong ke dalam Kelas Dinoflagellata dimana dalam jumlah yang besar dapat menimbulkan fenomena pasang merah (red tide).

Beberapa jenis dari Dinoflagellata diketahui dapat menimbulkan kematian massal pada ikan-ikan yang di perairan sekitar timbulnya red tide. Dinoflagellata juga dapat secara langsung membahayakan udang karena menimbulkan penyakit yang disebut Blunted Head Syndrom yaitu terjadinya pengikisan di kepala bagian anterior (rostrum dan antennula). Keterdapatan Dinoflagellata di sekitar area pertambakan perlu diwaspadai apalagi sampai ditemukan sebagai genus predominan. Oleh karena itu, upaya monitoring yang rutin dan data yang reliable merupakan langkah awal yang tepat untuk memastikan keberhasilan suatu usaha budidaya. Secara spasial komposisi jenis fitoplankton adalah sebagai berikut :

1. Perairan umum di sekitar kawasan didominasi oleh fitoplankton kelas Bacillariophyceae. Pada stasiun 2, 5, 6 dan 7 didominasi oleh Skeletonema. Pada badan Sungai Way Terusan (stasiun 1) didominasi oleh Coscinodiscus.

2. Lokasi sekitar pompa pembuangan utama dimana belum terjadi atau baru terjadi sedikit percampuran dengan air laut didominasi adalah fitoplankton dari kelas Cyanophyceae seperti Oscillatoria dan Nostoc serta kelas Bacillariophyceae seperti Skeletonema.

Komposisi fitoplankton di dalam kolam budidaya

Jumlah kelas fitoplankton di dalam kolam budidaya sama seperti di lingkungan yaitu Bacillariophyceae, Dinophyceae, Cyanophyceae, Chlorophyceae, Euglenophyceae, dan Chrysophyceae. Kelimpahan masing-masing kelas selama masa budidaya dari rata-rata 6 petak budidaya dapat dilihat pada Gambar 5 . Persentase Bacillariophyceae di dalam kolam budidaya tidak sebanyak di lingkungan. Cyanophyceae ditemukan dominan dari awal hingga pertengahan masa budidaya sekitar DOC 80 dan kondisi fitoplankton seperti ini kurang baik untuk udang. Kelimpahan Cyanophyceae yang tinggi tersebut disebabkan oleh rasio $\mathrm{N}$ : $\mathrm{P}$ yang rendah dimana rasio $\mathrm{N}$ : $\mathrm{P}$ yang terukur dari awal hingga akhir budidaya tidak melebihi $2: 1$. Jumlah Chlorophyceae kemudian meningkat dengan cepat mulai DOC 80 hingga panen dan penyebabnya masih belum diketahui. Cyanophyceae dan Dinophyceae merupakan kelas yang tidak diinginkan karena kedua kelas tersebut dapat menghasilkan racun bagi udang.

Menurut Lovell dan Sacky (1973) alga hijau biru mampu menghasilkan geosmin dan 2-methylisoborneol yang kemudian dieksresikan ke dalam perairan dan diserap oleh biota air sehingga organisme yang dibudidayakan berbau tidak sedap. Kelas Dinophyceae menghasilkan racun PSP (Paralytic Shellfish Poisoning), NSP (Neurotoxic Shellfish Poisoning) dan DSP (Diarrheic Shellfish Poisoning). Fitoplankton yang diharapkan untuk tumbuh adalah dari kelas Chlorophyceae dan Bacillariophyceae karena kedua kelas ini dapat dijadikan sebagai pakan alami bagi udang selain sebagai penambah oksigen di kolom air. Secara umum, keenam petak budidaya yang diamati didominasi oleh Cyanophyceae dan Chlorophyceae. Boyd (1990) menyatakan bahwa pada tambak di bagian Selatan Amerika biasanya alga hijau dan hijau-biru ditemukan dalam jumlah sangat banyak dengan persentase mencapai $90 \%$ atau lebih saat musim panas. 


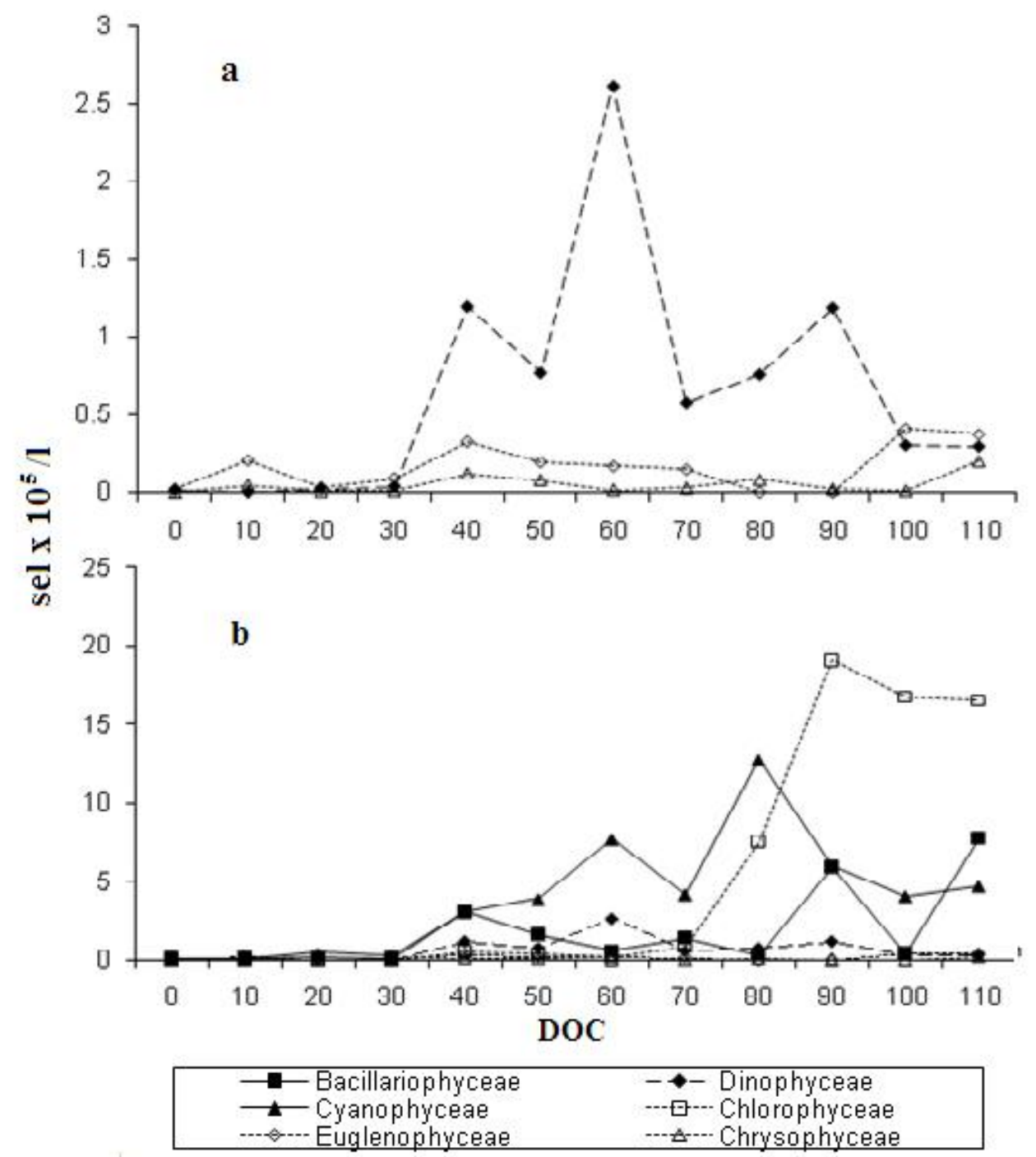

Gambar 5. Kelimpahan dari masing-masing kelas fitoplankton selama satu siklus budidaya (sel/l)

(a) tanpa Cyanophyceae, Chlorophyceae, dan Euglenophyceae

(b) dengan Cyanophyceae, Chlorophyceae, dan Euglenophyceae

Jika keenam kelas tersebut dijabarkan lebih spesifik ke dalam genus, maka akan ditemukan 18 genus predominan selama kurun waktu satu siklus budidaya. Genus predominan yang paling sering muncul adalah Oscillatoria dan Oocystis. Oocystis merupakan genus yang baik untuk berkembang di dalam tambak. Akan tetapi lain halnya dengan Oscillatoria, genus ini sebenarnya tidak diharapkan untuk tumbuh karena dapat menghasilkan racun yang berbahaya bagi udang. Menurut Isnansetyo dan Kurniastuty (1995), alga hijau-biru dari Familia Oscillatoriaceae diketahui dapat menimbulkan sindroma hemocytis enteristis pada krustasea dan ikan. Di tambak udang Litopenaeus vannamei di negara Brazil Casé et al. (2008) menemukan beberapa spesies yang sering muncul seperti Pseudoanabaena limnetica cf., Scrippsiella trochoidea, Gymnodinium sp., Cyclotella meneghiniana, dan Chlorella sp. Smith (1983) melaporkan 
bahwa rasio beban nutrien dapat menyebabkan efek selektif yang kuat terhadap komunitas fitoplankton. Di ekosistem perairan dangkal seperti tambak, ketersediaan fosfor dan nitrogen di air interstitial dapat menjadi sumber tambahan nutrien bagi ledakan populasi fitoplankton. Ditambahkan juga, sekitar $80 \%$ nitrogen yang masuk ke tambak melalui pakan udang tidak terkonversi menjadi biomassa udang, malahan berfungsi sebagai sumber nutrien fitoplankton (Sanders et al., 1987).

\section{Kelimpahan fitoplankton}

Kelimpahan fitoplankton di lingkungan

Pada Gambar 6 terdapat variasi bulanan kelimpahan fitoplankton secara temporal. Adapun nilai total kelimpahan fitoplankton yang ditemukan pada pengamatan bulan Juli dan Agustus masingmasing sebanyak 17.014 .793 sel/1 dan 15.027.065 sel/l. Stasiun 1 pada bulan Juli memiliki nilai kelimpahan fitoplankton terendah dari seluruh pengamatan dengan nilai kelimpahan sebesar 552 sel/l dan kelimpahan tertinggi terdapat di stasiun 3 pada bulan Agustus yaitu sebanyak $7.031 .983 \mathrm{sel} / 1$.

Pada bulan Juli 2008, kelimpahan fitoplankton setiap stasiunnya sangat bervariasi pada kisaran 552 - $6.978 .933 \mathrm{sel} / \mathrm{l}$. Pada bagian perairan yang sebelum adanya area pertambakan seperti sungai Way Terusan (1), kelimpahan fitoplankton yang didapatkan paling rendah dibandingkan stasiun-stasiun lainnya yaitu 552 sel/l. Kelimpahan tertinggi terdapat di stasiun 4, yaitu 6.978.933 sel/1 dan diikuti oleh stasiun 3 sebesar 5.764.117 sel/l. Hal tersebut disebabkan oleh lokasi stasiun 3 dan 4 merupakan point source buangan sisa budidaya udang yang berasal dari kawasan. Kelimpahan fitoplankton selanjutnya menurun seiring dengan perjalanan air limbah sepanjang saluran main outlet. Selama dalam saluran ini, air sisa budidaya mengalami pengenceran oleh air laut karena pasang dan sedimentasi, sehingga pada saat mencapai ujung pertemuan dengan perairan umum, yaitu stasiun outlet CPB Way Seputih (5) dan outlet CPB Sungai Burung (6) kelimpahan fitoplankton telah menurun masing-masing menjadi $1.055 .900 \mathrm{sel} / 1 \mathrm{dan}$ $2.636 .783 \mathrm{sel} / 1$. Kelimpahan fitoplankton di Sungai Burung (6) relatif lebih tinggi dibandingkan dengan outlet CPB Way Seputih (5) pada setiap bulan pengamatan karena letak stasiun 6 lebih dekat terhadap stasiun 4/pompa pembuangan utama yang merupakan pusat pembuangan air sisa budidaya. Berdasarkan pengukuran pada peta, rasio jarak antara stasiun 5 - Pompa 71 : stasiun 6 - Pompa 71 adalah 6,4 : 1 . Kelimpahan fitoplankton di stasiun 7 yang merupakan ujung pertemuan muara Sungai Way Seputih dengan laut juga telah menurun dibandingkan stasiun 5 dan 6 , yaitu sebesar 270.567 sel/l. 


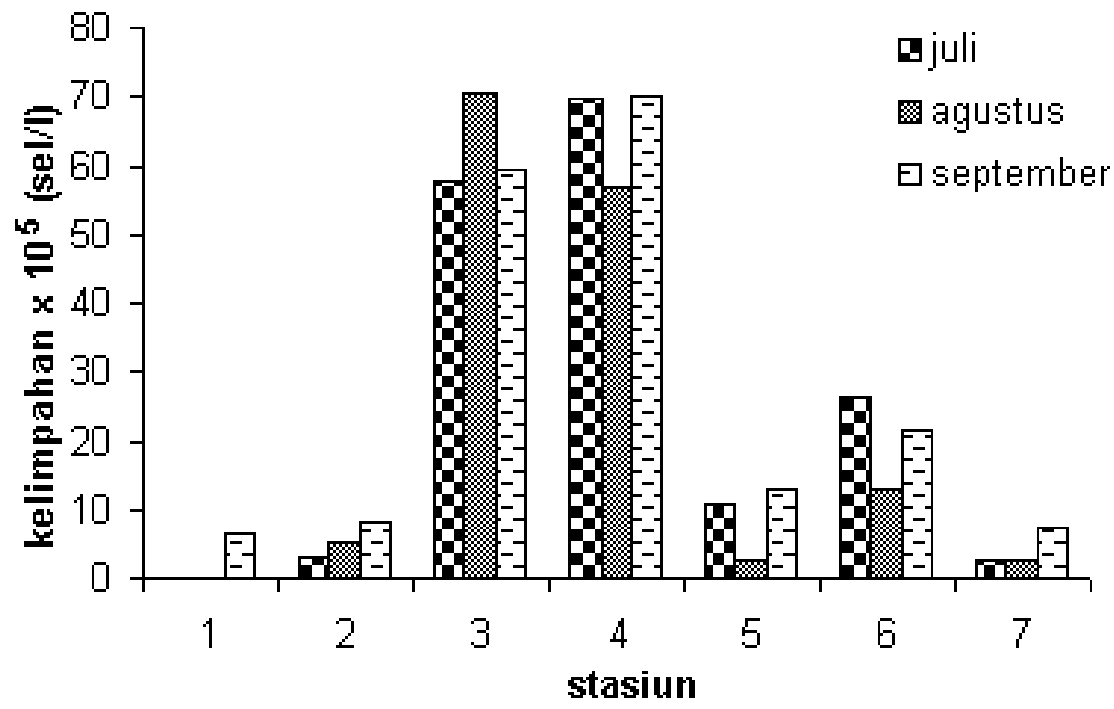

Keterangan :

St 1 : Sungai Way Terusan

St 2 : Pintu Air

St 3 : Sebelum Pompa Utama Blok 71

St 4 : Setelah Pompa Utama Blok 71

St 5 : Outlet CPB di Sungai Way Seputih

St 6 : Outlet CPB di Sungai Burung

St 7 : Muara

Gambar 6. Kelimpahan fitoplankton pada masing-masing stasiun

Kelimpahan fitoplankton secara spasial pada bulan Agustus memiliki pola yang hampir sama dengan bulan sebelumnya. Perbedaannya kali ini, kelimpahan tertinggi yaitu sebanyak 7.031 .983 sel/1 didapat di stasiun 3, sedangkan yang terendah tidak berbeda dari bulan sebelumnya yakni ditemukan di stasiun 1 dengan kelimpahan sebesar 2.507 sel/1. Kelimpahan fitoplankton yang ditemukan pada bulan September berbeda dibandingkan dengan bulan-bulan sebelumnya. Secara umum, kelimpahan fitoplankton meningkat di hampir semua lokasi pengamatan, kecuali stasiun 3. Dari segi letak, stasiun 3 memang tidak terhubung dengan stasiun lainnya karena stasiun ini merupakan bagian dari saluran suboutlet modul 15 blok 71. Air pada stasiun 3 hanya akan keluar menuju luar kawasan apabila pompa pembuangan utama dioperasikan.
Peningkatan paling signifikan terdapat di stasiun 1 (Way Terusan) dimana terjadi peningkatan kelimpahan hingga 263 kali dibandingkan bulan sebelumnya dengan nilai kelimpahan sebesar $650.000 \quad \mathrm{sel} / \mathrm{l}$. Peningkatan populasi fitoplankton secara drastis yang dikenal dengan istilah blooming ini mengindikasikan terjadinya penyuburan pada badan sungai tersebut.

Kelimpahan fitoplankton di dalam kolam budidaya

Kelimpahan total rata-rata fitoplankton yang dikumpulkan dari enam kolam budidaya selama masa budidaya ditunjukkan pada Tabel 7. Kelimpahan fitoplankton saat awal budidaya masih rendah yaitu 15.667 sel/l. Seiring dengan bertambahnya masa budidaya (DOC), maka akumulasi sisa pakan dan kotoran udang pun bertambah. Keduanya merupakan bahan 
organik yang kemudian akan diuraikan oleh bakteri menjadi senyawa-senyawa anorganik (seperti amonia, nitrat, nitrit, dan orthofosfat) sehingga perairan pun menjadi semakin subur. Peningkatan kesuburan sebagai akibat akumulasi sisa pakan dan kotoran udang selanjutnya berdampak pada peningkatan kelimpahan fitoplankton yang mencapai 3.211.389 sel/1 pada DOC 90.

Komunitas fitoplankton merupakan hal yang penting diperhatikan pada saat budidaya karena fitoplankton merupakan penyumbang oksigen selain kincir air dan mampu menyerap racun di perairan. Dengan bertambahnya kelimpahan fitoplankton, maka oksigen yang dapat dihasilkan pun akan lebih banyak. Namun, konsumsi oksigen pada malam hari pun akan bertambah sehingga mengancam ketersediaan oksigen bagi udang.

Tabel 7. Jumlah genus dan kelimpahan rata-rata dari 5 kolam budidaya selama satu siklus budidaya

\begin{tabular}{|c|c|r|r|}
\hline $\begin{array}{c}\text { DOC/Day of } \\
\text { Culture }\end{array}$ & Jumlah genus & Kelimpahan (sel/l) & $\begin{array}{r}\text { Simpangan } \\
\text { baku (sel/l) }\end{array}$ \\
\hline 0 & 10 & 15.667 & 9.767 \\
\hline 10 & 10 & 47.389 & 12.974 \\
\hline 20 & 15 & 63.944 & 39.891 \\
\hline 30 & 13 & 58.667 & 30.902 \\
\hline 40 & 12 & 832.500 & 458.241 \\
\hline 50 & 10 & 688.519 & 348.011 \\
\hline 60 & 16 & 1.133 .333 & 988.651 \\
\hline 70 & 13 & 711.574 & 226.535 \\
\hline 80 & 15 & 2.146 .111 & 403.091 \\
\hline 90 & 15 & 3.211 .389 & 2.335 .689 \\
\hline 100 & 14 & 2.196 .944 & 1.677 .812 \\
\hline 110 & 16 & 2.988 .056 & 2.239 .634 \\
\hline
\end{tabular}

Upaya pemeliharaan kestabilan fitoplankton yang umumnya dilakukan antara lain dengan melakukan pergantian sebagian air, melakukan siphon bahan organik di dasar kolam untuk mengeluarkan bahan organik yang tertumpuk, bahkan penambahan klorin atau BKC kadang sengaja dilakukan untuk mengurangi kelimpahan fitoplankton atau penambahan pupuk jika terjadi drop fitoplankton. Kelimpahan fitoplankton biasanya dideteksi dengan mengukur kecerahan. Kelimpahan fitoplankton selama budidaya dapat saja berfluktuasi selama satu siklus budidaya seperti yang terlihat pada Tabel 7 karena beberapa hal, misalnya pergantian air dan aktivitas siphon dasar kolam. Akan tetapi, dari pengamatan enam petak tambak kelimpahan fitoplankton tetap cenderung meningkat seiring peningkatan DOC. Standar deviasi dari rata-rata kelimpahan enam kolam sangat besar. Ini menunjukkan bahwa kondisi setiap tambak budidaya tidaklah sama, bahkan berbeda jauh. Kondisi setiap tambak memang akan berbeda-beda karena kondisinya sangat bergantung pada pengelola kolam tersebut atau yang lebih dikenal dengan sebutan Pond Operator (PO) dan pengelolaan tambak selalu disesuaikan dengan kondisi tambak tersebut.

\section{Parameter fisika-kimia perairan}

Lingkungan perairan sekitar

Keberadaan fitoplankton di suatu perairan dipengaruhi oleh kondisi perairan bersangkutan. Suhu rata-rata yang terukur selama pengamatan berada dalam kisaran (27 - 30,1) ${ }^{\circ} \mathrm{C}$. Nilai pH berada pada kisaran yang masih tergolong baik untuk perairan, yaitu antara $6,95-8,08$. 
TSS yang tinggi terdapat di stasiun 3 dan 4 masing-masing sebesar $161 \mathrm{mg} / \mathrm{l}$ dan $159 \mathrm{mg} / \mathrm{l}$, sedangkan terendah di stasiun 1 sebesar $15 \mathrm{mg} / \mathrm{l}$. Pada kedua ujung outlet CPB (stasiun 5 dan 6) konsentrasi TSS telah menurun menjadi hanya 59 - $66 \mathrm{mg} / \mathrm{l}$. Konsentrasi TSS tergolong tinggi di stasiun 2 yaitu sebesar $84 \mathrm{mg} / \mathrm{l}$. Tingginya konsentrasi TSS di lokasi ini disebabkan oleh adanya arus yang kuat di sekitar bangunan pemecah ombak. Nilai kecerahan berbanding terbalik dengan konsentrasi TSS, jika TSS tinggi maka kecerahan menjadi rendah.

Konsentrasi DO terendah terdapat di stasiun 3 dan 4, penyebabnya adalah limbah sisa budidaya di wilayah ini masih tinggi sehingga kebutuhan oksigen untuk dekomposisi juga besar. DO yang terukur di stasiun 3 adalah 1,4 - 2,7 mg/l dan stasiun 4 sebesar 2,1 - 2,9 mg/l, konsentrasi DO sedemikian rupa kurang baik untuk biota laut. Pada lokasi lainnya kandungan DO berada $\geq$ 3,5 mg/l.

Rendahnya kandungan DO di stasiun 3 dan 4 berimplikasi pada rendahnya kadar nitrat di kedua stasiun ini karena pada kadar DO yang rendah nitrogen akan bergerak menuju amonia. Hasilnya, amonia di kedua stasiun ini juga lebih tinggi dibandingkan stasiun-stasiun lainnya yaitu masing-masing sebesar $1,53 \mathrm{mg} / \mathrm{l}$ dan 1,60 mg/l. Tingginya kadar amonia mengindikasikan bahwa tingkat pencemaran bahan organik di kedua titik ini masih tinggi. Hal ini didukung juga dengan konsentrasi orthofosfat di stasiun 3 dan 4 yang masing-masing sebesar $0,93 \mathrm{mg} / \mathrm{l}$ dan $0,84 \mathrm{mg} / \mathrm{l}$. Keberadaan canal main outlet/saluran buangan utama yang panjang dan pengenceran limbah oleh air laut pada saluran ini tampaknya memang efektif untuk menurunkan kandungan nutrien sebelum mencapai perairan umum seperti halnya yang terjadi pada kelimpahan plankton. Hal ini terlihat dari penurunan kadar amonia dan orthofosfat yang signifikan pada stasiun 5 (Outlet CPB Way Seputih) dan stasiun 6 (Outlet CPB Sungai Burung) masing-masing menjadi $0,18 \mathrm{mg} / \mathrm{l}$ dan $0,29 \mathrm{mg} / \mathrm{l}$ untuk amonia serta $0,06 \mathrm{mg} / \mathrm{l}$ dan $0,05 \mathrm{mg} / \mathrm{l}$ untuk orthofosfat. Konsentrasi rata-rata orthofosfat yang terendah selama tiga bulan pengamatan terdapat di stasiun 1 , yaitu $0,01 \mathrm{mg} / \mathrm{l}$. Hasil analisis parameter fisika-kimia perairan di lingkungan selama pengamatan disajikan pada Gambar 8.

Kualitas Air Kolam budidaya

Kisaran $\mathrm{pH}$ selama budidaya masih terlihat stabil dengan kisaran 7,4 - 8,5. Kisaran $\mathrm{pH}$ yang baik di tambak sebaiknya 7,5 - 8,5. Salinitas berkisar antara 24 dan 34 psu. Menurut Boyd (1990), salinitas yang ideal untuk pertumbuhan $P$. vannamei adalah 15 sampai 25 psu, akan tetapi produksinya juga tetap baik pada salinitas lebih rendah ataupun lebih tinggi dari kisaran tersebut karena udang cenderung tahan akan perubahan salinitas asalkan perubahannya terjadi secara perlahan. Kandungan TSS cenderung semakin tinggi seiring dengan peningkatan umur budidaya dan sebaliknya dengan kecerahan. Penyebabnya adalah akumulasi sisa pakan, kotoran udang, dan fitoplankton seiring dengan bertambahnya DOC. Kandungan TSS yang diukur selama budidaya berkisar pada $148 \mathrm{mg} / \mathrm{l}-329 \mathrm{mg} / \mathrm{l}$, menurut Alabaster dan Lloyd (1982) in Effendi (2003) kandungan TSS tersebut kurang baik bagi kepentingan perikanan.

Selain itu, konsentrasi TAN, nitrit, nitrat dan orthofosfat juga cenderung meningkat seiring bertambahnya umur budidaya. Menurut Boyd (komunikasi pribadi, 2008), proses nitrifikasi di dalam tambak berlangsung dengan baik sehingga konsentrasi amonia tidak melebihi 1,74 mg/l. Namun, kandungan nitrat yang terukur tetap rendah yaitu berkisar pada $0,00 \mathrm{mg} / \mathrm{l}-0,60$ $\mathrm{mg} / \mathrm{l}$. Penyebabnya diduga karena kondisi oksigen di sedimen yang rendah, sehingga nitrat yang dihasilkan dari proses nitrifikasi di kolom air akan langsung mengalami denitrifikasi secepat laju nitrifikasi di kolom air. Konsekuensinya adalah kandungan nitrit menjadi tinggi dan hal ini terjadi karena nitrit yang dihasilkan dari proses denitrifikasi nitrat di dasar kolam terangkat ke kolom air 
akibat adanya kincir. Konsentrasi nitrit bahkan melebihi $3 \mathrm{mg} / \mathrm{l}$ pada DOC 80 . Akan tetapi menurut Boyd (komunikasi pribadi, 2008), konsentrasi tersebut tidak terlalu membahayakan udang. Kandungan orthofosfat juga meningkat seiring bertambahnya DOC. Penyebabnya adalah
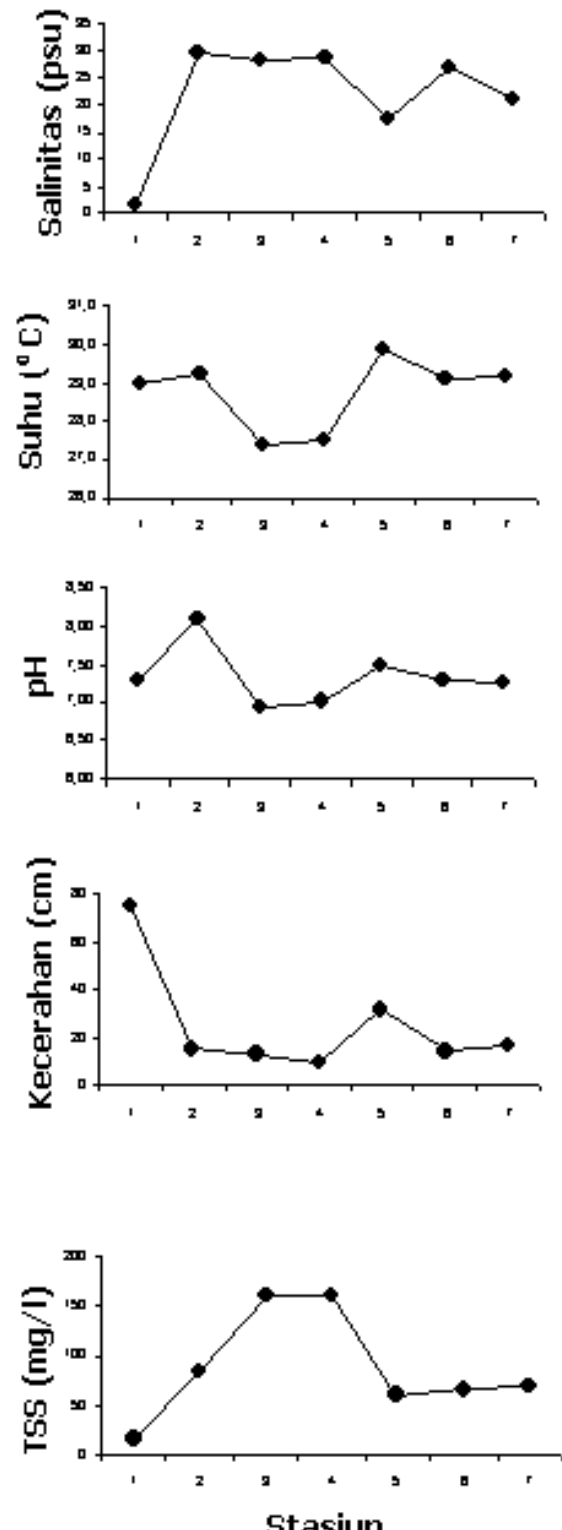

Stasiun dasar tambak yang tertutup plastik (full plastic), sedangkan plastik mencegah kontak antara air dan tanah sehingga orthofosfat tidak dapat terserap ke dalam tanah. Konsentrasi tertinggi dicapai pada DOC mendekati panen yaitu 3,77 mg/l pada DOC 100 .
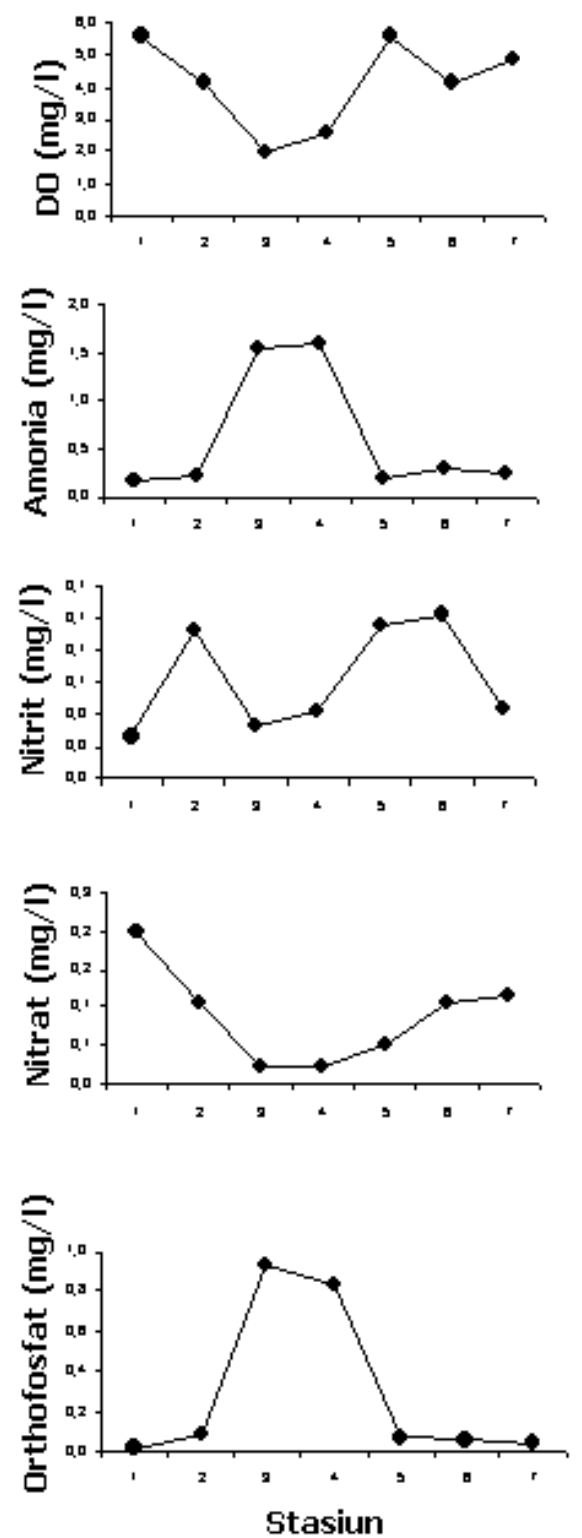

Gambar 8. Parameter fisika-kimia yang diukur di lingkungan

Kandungan DO minimum yang terukur selama pengamatan semakin rendah seiring dengan peningkatan DOC. Ada dua hal yang dapat menjadi kemungkinan penyebabnya, yaitu peningkatan populasi fitoplankton dan pertambahan biomassa udang. Dari DOC 70, 
mulai ditemukan konsentrasi DO minimum yang < 2,0 mg/l pada beberapa kolam. Nilai tersebut kurang baik bagi pertumbuhan udang. Menurut Towell et al. (2002) in Tjahyo et al. (2006) kandungan oksigen terlarut yang optimal untuk udang adalah 3 -
$7 \mathrm{mg} / \mathrm{l}$ dan menimbulkan stress jika kandungan oksigennya di bawah $2 \mathrm{mg} / \mathrm{l}$. Hasil analisis parameter fisika-kimia perairan pada tambak budidaya selama pengamatan disajikan pada Gambar 9.
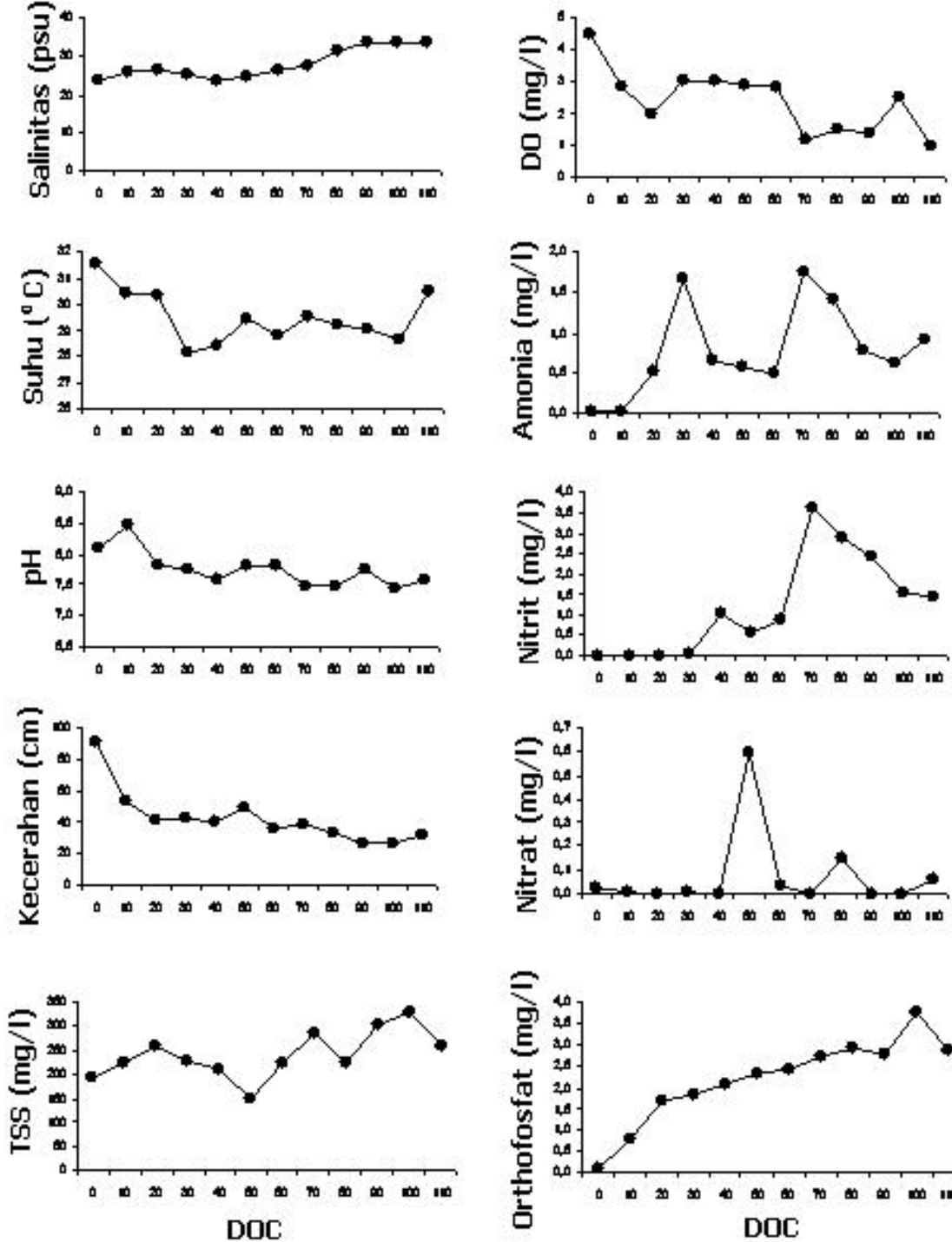

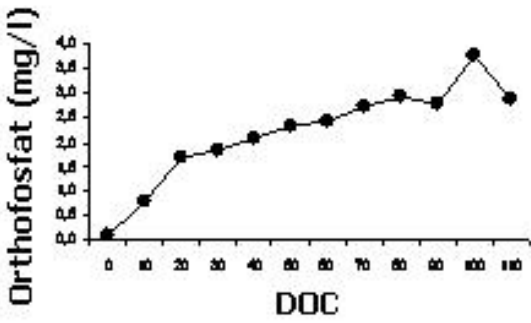

Gambar 9. Parameter fisika-kimia yang diukur di 5 kolam budidaya

Pengelompokan stasiun berdasarkan kelimpahan fitoplankton

Lingkungan

Dalam dendrogram pada Gambar 10 terlihat bahwa terdapat empat pengelompokan stasiun pada taraf kesamaan
$80 \%$. Kelimpahan fitoplankton di stasiun 1, 2, 5, dan 7 relatif dekat dan dapat dikatakan satu kelompok, sedangkan kelompok lainnya adalah stasiun 6, stasiun 3 dan stasiun 4 .

Kelimpahan fitoplankton di stasiun 3 dan 4 masih sangat tinggi. Ini diduga karena 
konsentrasi limbah di titik ini juga masih tinggi mengingat kedua titik ini terletak sangat dekat dengan pompa pembuangan utama blok 71. Namun, penyebab tingginya kelimpahan fitoplankton di kedua lokasi ini juga dapat dikarenakan perairannya yang tenang (arus lemah dilihat secara visual). Perairan yang tenang memungkinkan fitoplankton untuk tinggal lebih lama dan berkembangbiak sehingga terjadi akumulasi pada kedua lokasi tersebut. Akan tetapi ternyata stasiun 3 dan stasiun 4 adalah kelompok yang berbeda, penyebabnya adalah komposisi fitoplankton di dalamnya yang berbeda. Perairan di stasiun 3 mendapat pengaruh kuat dari dalam kawasan dan stasiun 4 telah tercampur dengan air laut, fitoplankton di laut didominasi oleh Bacillariophyceae dan di dalam tambak didominasi oleh Cyanophyceae dan Chlorophyceae.

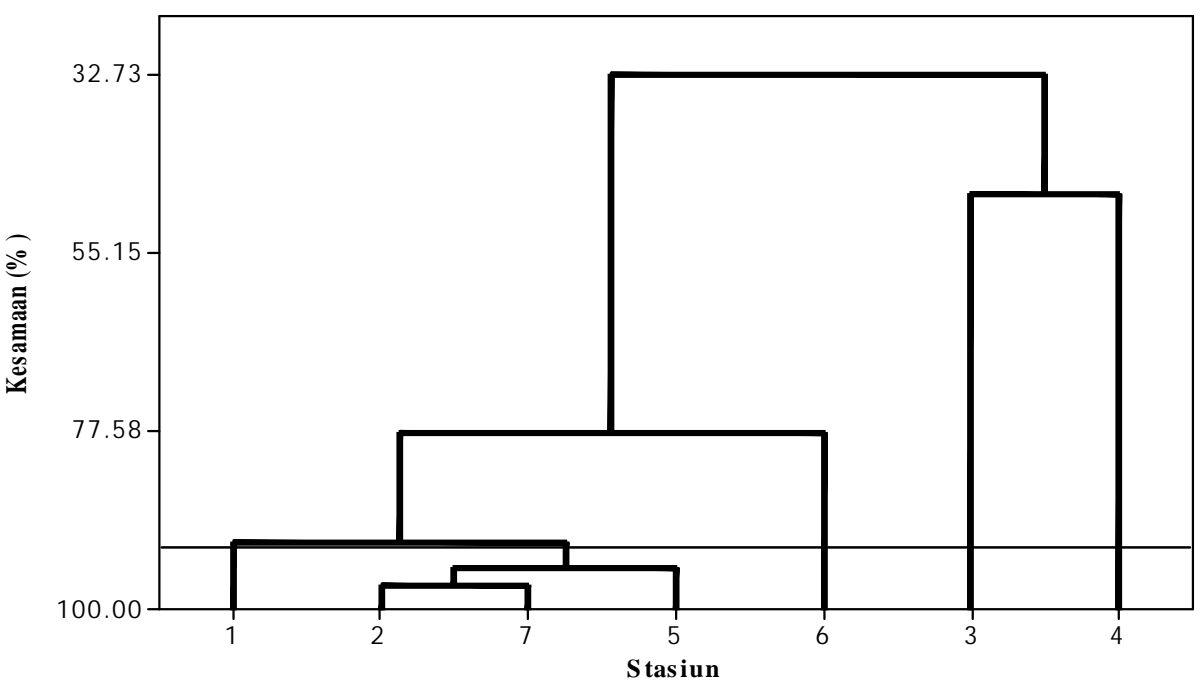

Gambar 10. Dendrogram pengelompokan stasiun berdasarkan kelimpahan rata-rata masingmasing genus selama tiga bulan pengamatan

Stasiun 1, 2, 5, dan 7 tergolong ke dalam satu kelompok pada tingkat kesamaan $80 \%$. Keempat stasiun ini terdapat di perairan umum sehingga dapat pula dikatakan bahwa dampak limbah budidaya tidak berpengaruh terhadap kelimpahan fitoplankton di lingkungan sekitar area pertambakan. Akan tetapi yang perlu diperhatikan adalah kelimpahan fitoplankton di stasiun 6 (outlet CPB Sungai Burung) masih tergolong tinggi sehingga stasiun ini membentuk kelompok sendiri. Kemungkinan penyebabnya adalah jarak stasiun 6 ke pompa pembuangan utama yang lebih dekat daripada outlet CPB Way Seputih (stasiun 5) yang menyebabkan limbah masih cukup pekat, sehingga akan lebih baik jika air sisa budidaya diarahkan keluar melalui stasiun 5 dengan mengatur kemiringan kedalaman saluran pembuangan utama (canal main outlet). Dengan mengeluarkan air sisa budidaya melewati stasiun 5, maka konsentrasi limbah yang masuk ke perairan umum diharapkan menjadi lebih rendah.

Kolam budidaya

Berdasarjan Uji Kruskal-Wallis pada selang kepercayaan $95 \%$ diketahui bahwa tidak semua DOC dari kolam budidaya yang diamati memiliki kelimpahan fitoplankton yang sama. Hal ini diperkuat dengan uji similaritas bahwa komunitas fitoplankton hanya memiliki kemiripan di atas $80 \%$ mulai 
dari awal budidaya hingga mencapai DOC 50 saja, sedangkan sisanya membentuk kelompok masing-masing. Berdasarkan dendrogram (Gambar 11) terlihat ada 6 kelompok DOC yakni DOC 70, DOC 80, DOC 90, DOC 100, DOC 110 membentuk kelompok masing-masing dan DOC $0-50$ membentuk satu kelompok.

Komunitas fitoplankton yang tidak stabil setelah DOC 50 ini perlu ditangani dengan baik pada budidaya selanjutnya agar tidak terjadi guncangan parameter kualitas air yang dapat menimbulkan stres pada udang. Komunitas fitoplankton yang stabil selama budidaya berperan sangat penting karena terkait dengan kompetisi pemanfaatan oksigen (dilihat dari segi kelimpahan fitoplankton) dan kesehatan udang (dilihat dari segi komposisi fitoplankton). Aktivitas siphon dasar tambak dan pergantian sebagian volume air yang telah diterapkan pada sistim budidaya di pertambakan ini merupakan cara yang sangat baik dalam rangka menjaga kestabilan komunitas fitoplankton di dalamnya. Oleh karena itu, untuk mengatasi masalah di atas maka aktivitas siphon dan pergantian massa air dapat dilakukan lebih sering pada saat umur budidaya (DOC) telah melewati 50 hari karena semakin besar ukuran udang maka potensi limbah yang akan dihasilkan pun semakin banyak. Limbah yang dihasilkan dari kegiatan budidaya udang dapat berasal dari beberapa sumber antara lain kotoran udang, kulit sisa moulting maupun sisa pakan yang apabila dibiarkan menumpuk di dasar kolam akan terurai menjadi nutrien. Limbah tersebut harus ditangani dengan baik karena akan ada konsekuensi yang timbul jika pengelolaannya kurang diperhatikan. Ada tiga konsekuensi yang dapat timbul jika limbah ini tidak dikeluarkan dari dalam kolam, yaitu deplesi oksigen akibat aktivitas dekomposisi oleh bakteri, blooming fitoplankton, dan berkurangnya ruang gerak bagi udang sehingga dapat meningkatkan potensi kanibalisme. Selain itu, perlu diperhatikan juga bahwa dari segi proporsinya ternyata Oscillatoria masih sering mendominasi di kolam-kolam budidaya yang diamati. Oleh karena itu, perlu ditemukan pemecahan masalah ini agar fitoplankton yang berkembang berasal dari jenis-jenis yang menguntungkan.

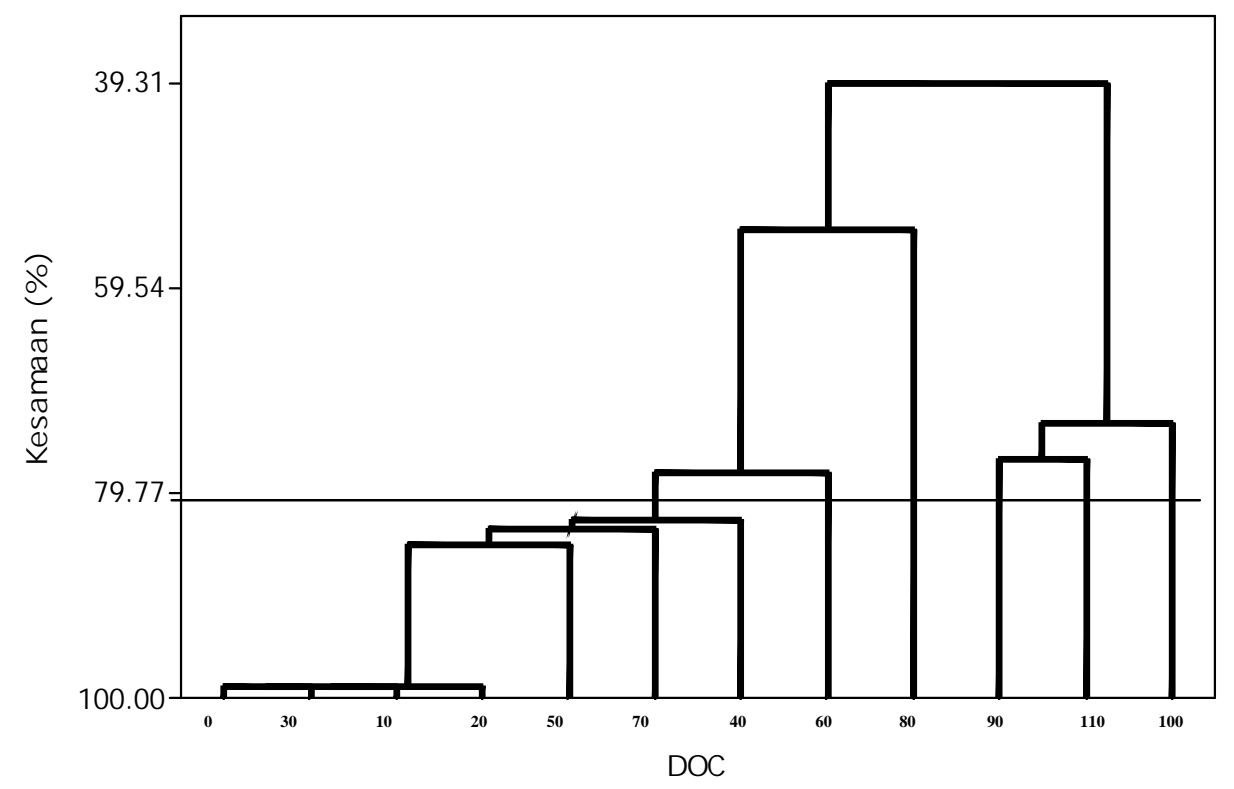

Gambar 11. Dendrogram pengelompokan DOC berdasarkan kelimpahan rata-rata masing-masing genus dari 5 kolam budidaya 


\section{Analisis komponen utama}

Lingkungan

Korelasi antara kelimpahan

fitoplankton dan parameter fisika-kimia perairan serta korelasi antara parameter fisika-kimia itu sendiri diketahui dengan menggunakan analisis komponen utama. Korelasi tersebut dapat dilihat pada Gambar 12. Kelimpahan fitoplankton berkorelasi positif terhadap Dissolved Inorganic Phosphate (Orthofosfat), Dissolved Inorganic Ammonia (DIN), TSS, dan salinitas, sedangkan kecerahan berbanding terbalik terhadap kelimpahan fitoplankton. DIN merupakan penjumlahan dari amonia, nitrat dan nitrit, lalu DIP adalah orthofosfat. Jika dilihat pada matriks korelasi, DIN dan DIP merupakan parameter yang paling erat korelasinya dengan fitoplankton. Nilai korelasi fitoplankton terhadap DIN dan DIP masing-masing sebesar 0,986 dan 0,974. Korelasi yang sangat erat juga terlihat antara fitoplankton dan TSS yaitu sebesar 0,927 yang dapat menandakan bahwa sebagian besar TSS yang terkandung dalam perairan di area pertambakan ini terdiri dari fitoplankton. Namun, hubungan antara kelimpahan fitoplankton terhadap salinitas dan kecerahan tidak terlalu erat karena korelasinya masih sekitar 0,500.

Gambar 12(b) menunjukkan penciri stasiun berdasarkan parameter-parameter yang diukur. Dari gambar terlihat bahwa stasiun 3 dan 4 mengelompok dicirikan dengan kelimpahan fitoplankton, DIN, dan DIP yang mirip. Pada kedua stasiun ini kelimpahan fitoplankton, konsentrasi DIN, dan konsentrasi DIP ditemukan dalam konsentrasi yang masih tinggi. Stasiun 1 juga terpisah dengan stasiun lainnya dan dicirikan nilai kecerahan, nilai kecerahan pada stasiun ini paling tinggi di antara stasiun lainnya.

Kolam budidaya

Gambar 13 menunjukkan hasil analisis komponen utama antar fitoplankton, DIN, DIP, TSS, kecerahan, dan salinitas. Kelimpahan fitoplankton di dalam tambak berkorelasi erat dengan DIP dan kecerahan dengan nilai korelasi 0,739 dan -0,646. Korelasi yang tidak erat antara fitoplankton dan TSS diduga disebabkan waktu pengambilan sampel berhimpitan dengan waktu pemberian pakan sehingga nilai TSS pada saat pengukuran juga ikut terpengaruh oleh pakan, sedangkan dengan DIN masih belum diketahui dengan jelas.

Korelasi yang erat ditemukan terhadap salinitas yaitu sebesar 0,909. Kelimpahan fitoplankton cenderung meningkat seiring bertambahnya waktu dalam satu siklus budidaya karena bertambahnya unsur hara hasil dekomposisi bahan organik. Salinitas pun juga meningkat seiring bertambahnya umur budidaya. Evaporasi yang terjadi di siang hari akan membuat kadar garam di dalam kolam meningkat karena volume air berkurang. Pada saat volume air berkurang petambak menambahkan air dari luar untuk menjaga kedalaman kolam. Hal yang demikian terjadi terus menerus sehingga kadar garam di dalam kolam semakin meningkat hingga akhir budidaya. Dengan demikian, korelasi antara kelimpahan fitoplankton dan salinitas menjadi erat. 
Dinamika Komunitas Fitoplankton

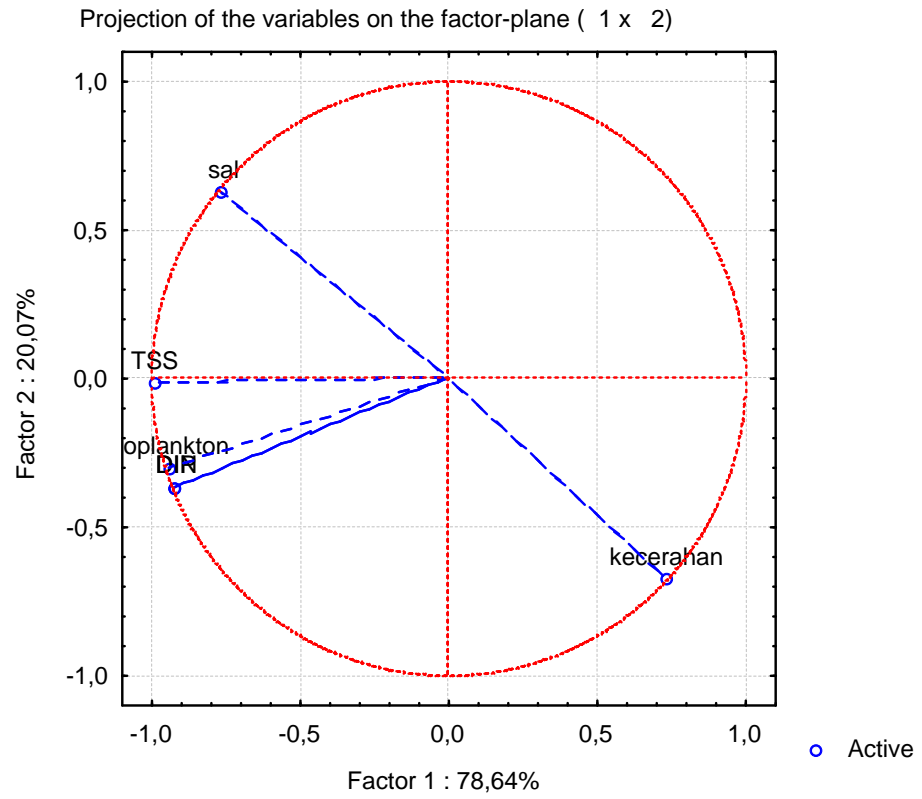

(a)

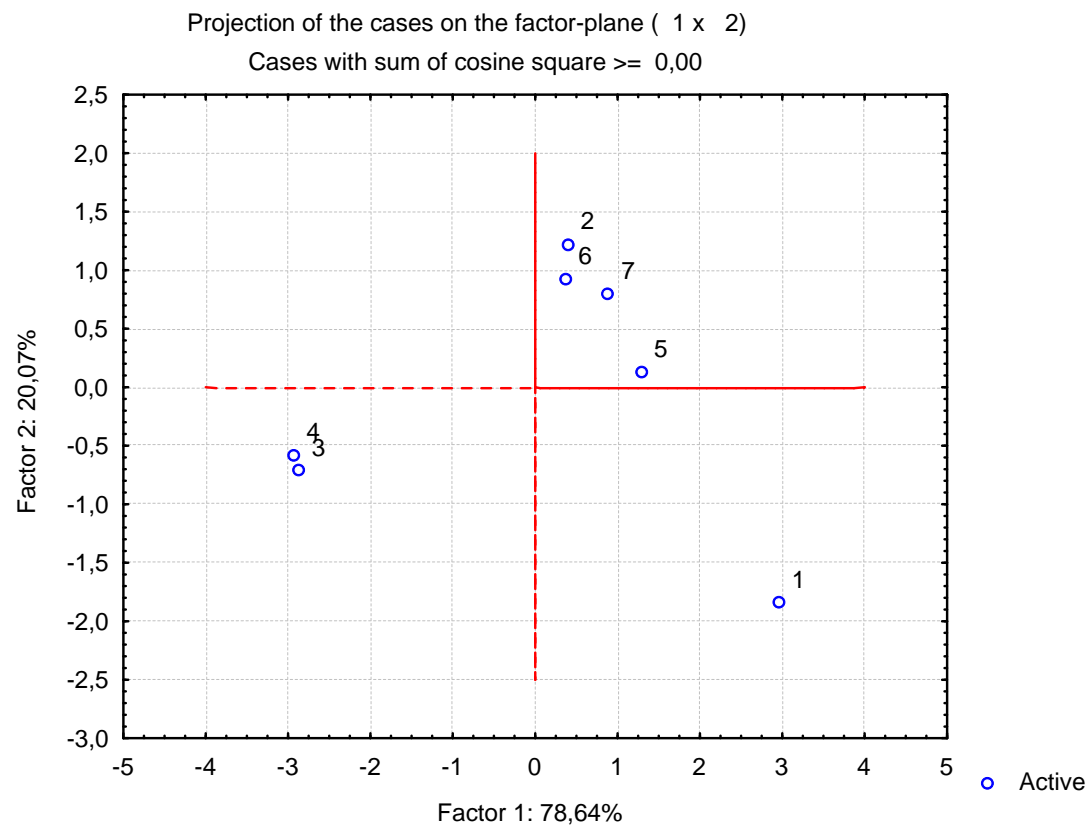

(b)

Gambar 12. Analisis komponen utama di lingkungan

(a) Korelasi antara parameter yang diamati

(b) Penyebaran stasiun berdasarkan parameter yang diamati 


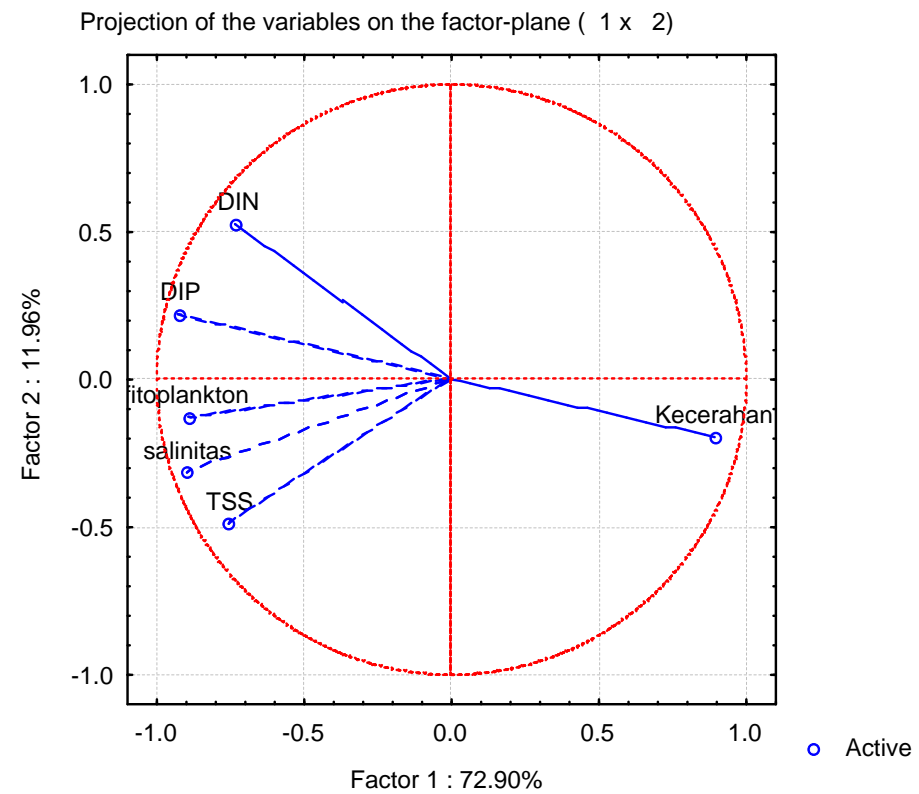

(a)

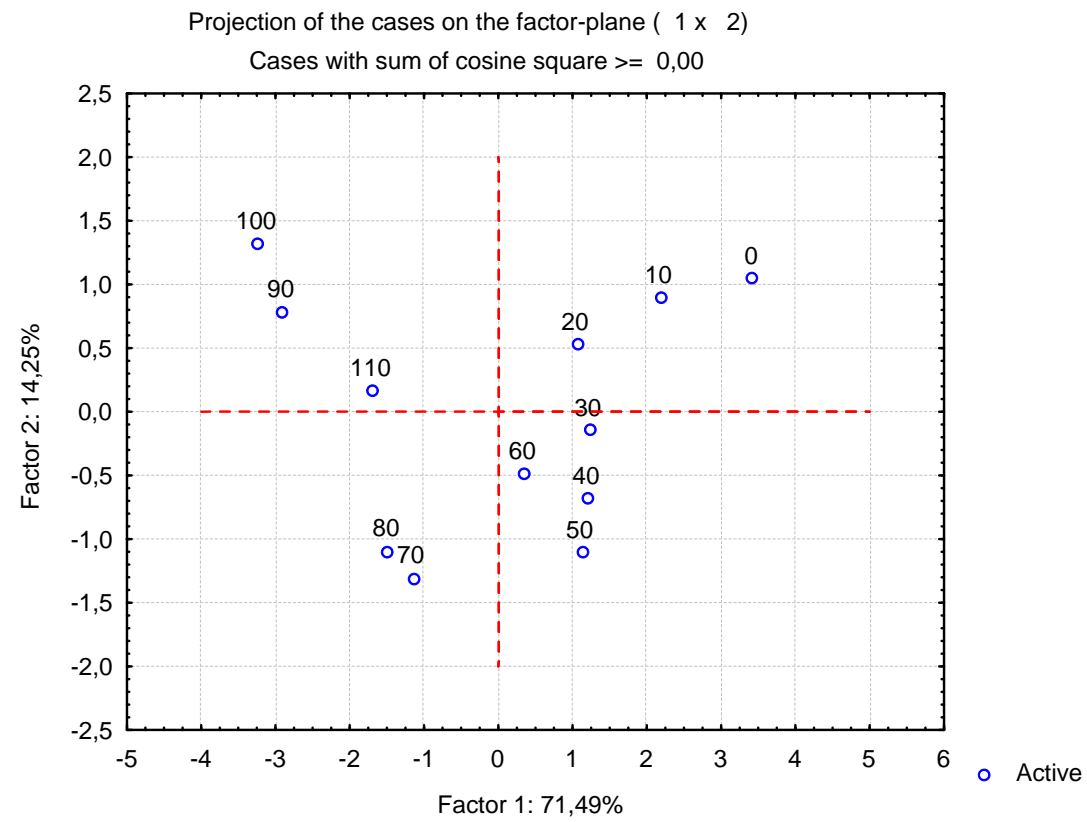

(b)

Gambar 13. Analisis komponen utama di kolam budidaya

(a) Korelasi antara parameter yang diamati

(b) Penyebaran stasiun berdasarkan parameter yang diamati

\section{KESIMPULAN}

Fitoplankton yang ditemukan di area pertambakan terdiri dari 47 genus dari enam kelas. Fitoplankton di dalam petak budidaya didominasi oleh kelas Cyanophyceae dan
Chlorophycea dengan genus Oscillatoria dan Oocystis dengan kelimpahan total berkisar 15.667 - 3.211.389 sel/l. Fitoplankton di lingkungan sekitar tambak didominasi oleh kelas Bacillariophyceae dan Cyanophyceae. 
Komposisi fitoplankton berdasarkan genus didominasi oleh Skeletonema dan Oscillatoria. Kelimpahan total berkisar antara 552 - $7.031 .983 \mathrm{sel} / \mathrm{l}$ dan fitoplankton terkonsentrasi di sekitar pompa pembuangan utama. Secara umum, limbah budidaya tidak mempengaruhi kelimpahan fitoplankton di perairan sekitarnya.

Kelimpahan fitoplankton di perairan sekitar area pertambakan berkorelasi erat dengan Dissolved Inorganic Nitrogen (DIN), Dissolved Inorganic Phosphate (DIP), dan TSS. Pada kolam budidaya, kelimpahan fitoplankton berkorelasi erat dengan DIP, kecerahan, dan salinitas.

\section{UCAPAN TERIMA KASIH}

Penelitian ini dapat dilakukan atas kebaikan PT. Centralpertiwi Bahari (CPB) yang telah menyediakan fasilitas dan dukungan selama penelitian. Pengambilan sampel dan analisis data dilakukan oleh Feridian Efinurfajri.

DAFTAR PUSTAKA

APHA (American Public Health Association). 1989. Standard Method for The Examination of Water and Waste Water. American Public Health Association. Water Pollution Control Federation. Port City Press. Baltimore, Mariland. $1202 \mathrm{p}$.

Arinardi, O. H, Trimaningsih dan Sudirdjo. 1994. Pengantar tentang plankton serta kisaran kelimpahan dan plankton predominan di sekitar Pulau Jawa dan Bali. Puslitbang Oseanologi-LIPI Jakarta.108 hal.

Arinardi, O.H., Trimaningsih, S.H. Riyono, E. Asnaryanti. 1995. Kisaran kelimpahan dan komposisi plankton predominan di sekitar Pulau Sumatra. Pusat Penelitian dan Pengembangan Oseanografi. Lembaga Ilmu Pengetahuan Indonesia. 110 hal.

Arinardi, O.H., Trimaningsih, Sudirdjo, Sugestiningsih dan S. H. Riyono. 1997. Kisaran kelimpahan dan komposisi plankton predominan di perairan Kawasan Timur Indonesia.
Pusat Penelitian dan Pengembangan Oseanografi. Lembaga Ilmu Pengetahuan Indonesia. Jakarta. 140 hal.

Baffico, G.D. and F. L. Pedrozo. 1996. Growth factors controlling periphyton production in a temperate reservoir in Patagonia used for fish farming. Lakes \& Reservoirs: Research \& Management 2 (3-4): 243-249.

Boyd, C.E. 1989. Water Quality Management and Aeration in Shrimp Farming. Auburn University. Alabama. 84 p.

Boyd, C.E. 1990. Water Quality in Ponds for Aquaculture. Auburn University. Alabama. 482p.

Briggs, M.R.P. and S. J. Funge-Smith. 1994. A nutrient budget of some intensive marine shrimp ponds in Thailand. Aquaculture and Fisheries Management 25: 789-811.

Burford, M.A. and P. M. Glibert. 1999. Short-term nitrogen uptake and regeneration in early and late growth phase shrimp ponds. Aquaculture Research 30: 1-13.

Burford, M. A., S.D. Costanzo, W.C. Dennison, C.J. Jackson, A.B. Jones, A.D. McKinnon, N.P. Preston and L.A. Trott. 2003. A synthesis of dominant ecological processes in intensive shrimp ponds and adjacent coastal environments in NE Australia. Marine Pollution Bulletin 46: 1456-1469.

Casé, M., E. E. Leça, S. N. Leitão, E.. E. Sant'Anna, R. Schwamborn and A. T. de Moraes Junior. 2008. Plankton community as an indicator of water quality in tropical shrimp culture ponds. Marine Pollution Bulletin 56: 1343-1352.

Davis, C.C. 1955. The Marine and Freshwater Plankton. Michigan State University. Academic Press. New York. 229 p. 
Edhy, W.A., J. Pribadi, dan Kurniawan. 2003. Johnson, R.I., O. Grahl-Nielsen, B.T.

Plankton di lingkungan PT.

Centralpertiwi Bahari: suatu pendekatan biologi dan manajemen plankton dalam budidaya udang. Laboratorium Central Department Aquaculture Division PT. Centralpertiwi Bahari (tidak dipublikasikan).

Effendi, H. 2003. Telaah Kualitas Air Bagi Pengelolaan Sumberdaya dan Lingkungan Perairan. Kanisius. Yogyakarta. 258 hal.

Funge-Smith, S.J. and M.R.P. Briggs. 1998. Nutrient budgets in intensiveshrimp ponds: implications for sustainability. Aquaculture 164: 117-133.

Goldman, C.R. dan A.J. Horne. 1983. Limnology. Mc Graw Hill International Book Company. Tokyo. $563 \mathrm{p}$.

Grant, J., A. Hatcher, D.B. Scott, P. Pocklington, C.T. Schafer and G.V. Winters. 1995. A multidisciplinary approach to evaluating impacts of shellfish aquaculture on benthic communities. Estuaries 18: 124-144.

Hensey, M.P., 1991. Environmental monitoring for fish farms. In: DePauw, N. and J. Joyce (Eds.). Aquaculture and the Environment. Special Publication of the European Aquaculture Society, Oxford, England. pp. 536.

Isnansetyo, A. dan Kurniastuty. 1995. Teknik Kultur Phytoplankton dan Zooplankton Pakan Alami Untuk Pembenihan Organisme Laut. Kanisius. Yogyakarta. 116 hal.

James, A. and L. Evison. 1979. Biological Indicators of Water Quality. John Willey \& Sons. New York.

Jackson, C. N. Preston, P. Thompson and M. Burford. 2003. Nitrogen budget and effluent nitrogen components at an intensive shrimp farm. Aquaculture 218: 397-411.
Lunestad. 1993. Environmental Distribution on Organic Waste From A Marine Fish Farms Aquaculture.

Jones, A.B., M.J. O'Donohue, J. Udy and W.C. Dennison. 2001. Assessing ecological impacts of shrimp and sewage effluent: biological indicators with standard water quality analyses. Estuarine, Coastal and Shelf Science 52: 91-109.

Landesman, L. 1994. Negative impacts of coastal aquaculture development. World Aquaculture 25: 12-17.

Lacerda, L.D., A.G. Vaisman, L.P. Maia, E. Cunha and C.A.R. Silva. 2006. Relative importance of nitrogen and phosphorus emissions from shrimp farming and other anthropogenic sources for six estuaries along the NE Brazilian coast. Aquaculture 253: 433-446.

Lovell, R.T. and Sackey, L.A. 1973. Absorption by channel catfish of earthy-musty flavor compounds synthesized by cultures of blue-green algae. Transactions of the American Fisheries Society 102 (4): 774- 777.

Mackentum, K.M. 1969. The Practice of Water Pollution Biology. United States Departement of Interior, Federal Water Pollution Control Administration, Division of Technical Support. $411 \mathrm{p}$

Mc Donald, M.E., C.A. Tikkanen, R.P. Axler, C.P. Larsen, dan G. Host. 1996. Fish Stimulation Culture Model For Aquaculture Wasteload Application. Aquaculture Engineering.

Mizuno, T. 1979. Illustration of The Freshwater Plankton of Japan. Hoikusha Publishing Co., Ltd. Japan. 335p.

Moriarty, D.J.W. 1997. The role of microorganisms in aquaculture ponds. Aquaculture 151: 333-49.

Naylor, R.L., R. J. Goldburg, H. Mooney, M. Beveridge, J. Clay, C. Folke, N. 
Kautsky, J. Lubchenco, J. Primavera and M. Williams. 1998. Nature's subsidies to shrimp and salmon farming. Science 282: 883-884.

Nontji, A. 1984. Biomassa dan Produktivitas Fitoplankton di perairan Teluk Jakarta serta Kaitannya dengan Faktor-faktor Lingkungan. Disertasi. Fakultas Pasca Sarjana Institut Pertanian Bogor. Bogor.

Nontji, A. 2006. Tiada Kehidupan di Bumi Tanpa keberadaan Plankton. Lembaga Ilmu Pengetahuan Indonesia. Pusat Penelitian Oseanografi. Jakarta. 199 hal.

Nontji, A. 2007. Laut Nusantara. Penerbit Djambatan. Jakarta. 372 hal.

Nybakken, J.W. 1992. Biologi Laut: Suatu Pendekatan Ekologis. Alih bahasa : H. M. Eidman, D. G. Koesoebiono, M. Bengen. PT. Gramedia. Jakarta. $459 \mathrm{p}$.

Odum, E.P. 1971. Fundamentals of Ecology. $3^{\text {rd }}$ edition. W. B. Sounders Co. Philadephia. 574 p.

Paez-Osuna, F. 2001. The environmental impact of shrimp aquaculture:causes, effects and mitigating alternatives. Environmental Management 28: 131-140.

Plinski, M. dan T. Jozwiak. 1999. Temperature and $\mathrm{N}$ : $\mathrm{P}$ Ratio as Factors Causing Blooms of BlueGreen Algae in The Gulf of Gdansk. Oceanologia 41 (1): 73-80.

Preston, N.P., C. Jackson, P.A. Thompson, M. Austin and M. Burford.2000. Prawn farm effluent: composition, origin and treatment. Fishing Research and Development Corporation Final Report 95/162. FRDC, Canberra.

Prowse, G.A. 1962. The use of fertilizers in fish culture. Proc. Indo. Pacific. Fish Coun. 9 (2-3): 73-75.

Pruder, G.D. 1992. Marine shrimp effluent: characterisation and environmental impact. In: J. Wyban (Ed.).
Proceedings of the Special Session on Shrimp Farming. World Aquaculture Society, Baton Rouge, pp. 187-194.

Raymont, J.E.G. 1963. Plankton and productivity in the ocean. Pergamon Press, Oxford and New York. 660 pp.

Robertson, A.I. and M.J. Phillips. 1995. Mangroves as filters of shrimp pond effluents: predictions and biogeochemical research needs. Hydrobiologia 295: 311-321.

Saeni, M.S. 1989. Kimia Lingkungan. PAUIPB. Bogor. 177 hal.

Sanders, J. 2004. Phytoplankton \& Climate Change: Model Shows Long-Held Constant in Ocean Nutrient Ratio May Vary as Ecological Conditions Change. Georgia Institute of Technology. Georgia.

Samocha, T.M. and A.L. Lawrence. 1997. Shrimp farms' effluent waters, environmental impact and potential treatment methods. In: B.J. Keller (Ed.). Interactions Between Cultured Species and Naturally Occurring Species in the Environment. pp. 3538.

Sansanyuth, P., A. Phadungchep, S. Ngammkontha, S. Ngdngam, P. Sukasem, H. Hoshino and M.S. Ttabucanon. 1996. Shrimp pond effluent: pollution problems and treatment by constructed wetlands. Water Science and Technology 34: 93-98.

Smith, J. M. 1983. The effects of the Cedar Bayou electric generating station on phytoplankton in adjacent waters. MSc thesis, Texas A\&M University, College Station, TX.

Smith, V.H. G. D. Tilman, and J. C. Nekola. 1999. Eutrophication: impacts of excess nutrient inputs on freshwater, marine and terrestrial ecosystems. Environmental Pollution 100: 179196. 
Sumich, J.L. 1988. An Introduction to the Biology of Marine Life. Wm. C. Brown Publisher. Dubuque. 425 p.

Tjahyo, D.W.H, E. S. Kartamihardja, dan S. E. Purnamaningtyas. 2006. Kualitas Air, Produktivitas Primer, dan Potensi Ikan Waduk Darma Untuk Mendukung Kehidupan dan Pertumbuhan Udang Galah (Macrobrachium rosenbergii) yang Diintroduksikan. Jurnal Penelitian Perikanan Indonesia 12 No. 1.

Wetzel, R.G. 2001. Limnology Lake and River Ecosystems. $3^{\text {rd }}$ edition. Academic Press. California. 985p.

Wolanski, E., S. Spagnol, S. Thomas, K. Moore, D.M. Alongi, L.A. Trott and A. Davidson. 2000. Modeling and visualizing the fate of shrimp pond effluent in a mangrove-fringed tidal creek. Estuarine, Coastal and Shelf Science 50: 85-97.

Yamaji, I.E. 1996. Illustration of The Marine Plankton of Japan. Hoikusha Publishing Co., Ltd. Osaka. Japan. 987p. 